\title{
Microbial inputs at the litter layer translate climate into altered organic matter properties
}

\section{Kohl, Lukas}

2021-01

Kohl , L , Myers-Pigg , A, Edwards , K A , Billings , S A, Warren , J , Podrebarac , F \& Ziegler , S E 2021 , ' Microbial inputs at the litter layer translate climate into altered organic matter properties ' , Global Change Biology , vol. 27 , no. 2 , pp. 435-453 . https://doi.org/10.1111/gcb.15420

http://hdl.handle.net/10138/335756

https://doi.org/10.1111/gcb.15420

cc_by_nc

acceptedVersion

Downloaded from Helda, University of Helsinki institutional repository.

This is an electronic reprint of the original article.

This reprint may differ from the original in pagination and typographic detail.

Please cite the original version. 


\section{Microbial inputs at the litter layer translate climate into altered organic matter properties}

2 Lukas Kohl ${ }^{a, b, c}$, Allison Myers-Pigga,d, Kate A. Edwards ${ }^{e, f}$, Sharon A. Billings ${ }^{g}$, Jamie Warren ${ }^{a, h}$, Frances

3 Podrebarac ${ }^{a, i}$, Susan E. Ziegler ${ }^{a}$

$4 \quad{ }^{a}$ Department of Earth Sciences, Memorial University, 300 Prince Philip Dr., St. John's, A1B 3X5, NL, Canada

$5 \quad{ }^{b}$ Department of Agricultural Sciences, Helsinki University, Viikinkaari 9, 00790 Helsinki, Finland

6 'Institute for Atmospheric and Earth System Research / Forest Sciences, Faculty of Agriculture and Forestry,

7 University of Helsinki, Viikinkaari 9, 00790 Helsinki, Finland

$8 \quad$ Present address: Marine Sciences Laboratory, Pacific Northwest National Laboratory, Sequim, WA USA

$9{ }^{e}$ Natural Resources Canada, Canadian Forest Service, Atlantic Forestry Centre, 26 University Drive, Corner Brook, 10 A2H 6J3, NL, Canada

11 fPresent address: Natural Resources Canada, Canadian Forest Service, 580 Booth St., Ottawa, ON, K1A OE4

$12{ }^{g}$ Department of Ecology and Evolutionary Biology, Kansas Biological Survey, University of Kansas, 2101 Constant 13 Ave., Lawrence, 66047, KS, USA

14 hPresent address: Natural Resources Canada, Canadian Forest Service, Atlantic Forestry Centre, 26 University Drive, 15 Corner Brook, A2H 6J3, NL, Canada

16 iPresent address: Genetics and Sustainable Agriculture Research, U.S. Agricultural Research Service, Mississippi 17 State, 39762, U.S.A.

18 Corresponding author: Lukas Kohl, email lukas.kohl@helsinki.fi, phone +358 406233339 ,

19 ORCIDs:

20 LK: 0000-0002-5902-9444

21 SEZ 0000-0003-0708-1336

22

23 Word count: Abstract 299 words, Introduction to Discussion: 8610

24 Keywords: litter decomposition; climate transect; fungi:bacteria; CP-MAS ${ }^{13} \mathrm{C}-\mathrm{NMR}$; boreal 25 forest; PLFA; necromass; ${ }^{13} \mathrm{C}$ 


\section{Abstract}

Plant litter chemistry is altered during decomposition but it remains unknown if these alterations, and thus the composition of residual litter, will change in response to climate. Selective microbial mineralization of litter components and the accumulation of microbial necromass can drive litter compositional change, but the extent to which these mechanisms respond to climate remains poorly understood. We addressed this knowledge gap by studying needle litter decomposition along a boreal forest climate transect. Specifically, we investigated how the composition and/or metabolism of the decomposer community varies with climate, and if that variation is associated with distinct modifications of litter chemistry during decomposition. We analyzed the composition of microbial phospholipid fatty acids (PLFA) in the litter layer and measured natural abundance

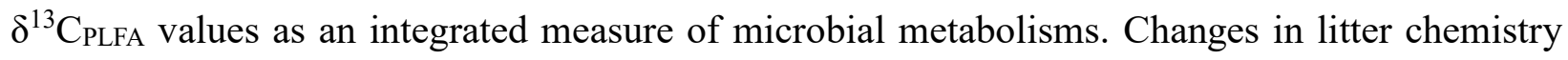
and $\delta^{13} \mathrm{C}$ values were measured in litterbag experiments conducted at each transect site. A warmer climate was associated with higher litter nitrogen concentrations as well as altered microbial community structure (lower fungi:bacteria ratios) and microbial metabolism (higher $\delta^{13} \mathrm{CPLFA}_{\mathrm{P}}$ ). Litter in warmer transect regions accumulated less aliphatic-C (lipids, waxes) and retained more O-alkyl-C (carbohydrates), consistent with enhanced ${ }^{13} \mathrm{C}$-enrichment in residual litter, than in colder regions. These results suggest that chemical changes during litter decomposition will change with climate, driven primarily by indirect climate effects (e.g. greater nitrogen availability and decreased fungi:bacteria ratios) rather than direct temperature effects. A positive correlation change in litter chemistry is driven more by distinct microbial necromass inputs than differences in the selective removal of litter components. Our study highlights the role that microbial inputs during early litter decomposition can play in shaping surface litter contribution to soil organic matter as it responds to climate warming effects such as greater nitrogen availability.

\section{Introduction}

Plant detritus (litter) inputs are a key factor shaping soil properties including the amount of soil organic matter (SOM) stored in a given soil, as well as its chemical composition. Global aboveground litterfall accounts for 20-25 Pg carbon (C) annually (Matthews, 1997). Approximately $80 \%$ of the foliar litter $\mathrm{C}$ decomposes rapidly (within months to years) while the residual $\mathrm{C}$ is introduced into the soil system (Prescott, 2010). These inputs replenish SOM stocks (Prescott, 2010), but also stimulate the decomposition of other, less labile SOM components ('priming effect'; Kuzyakov et al., 2000; Löhnis, 1926). The chemical composition of these inputs is an important determinant of the extent to which these inputs support SOM accrual or decomposition (Chao et al., 2019; Cotrufo, Wallenstein, Boot, Denef, \& Paul, 2013; Liu et al., 2020; Qiao et al., 2016; Stewart, Moturi, Follett, \& Halvorson, 2015) and a key driver of the chemical and biological properties of SOM (Kohl et al., 2018; Quideau et al., 2001; VandenEnden et al., 2018). Predicting future SOM stocks and properties therefore requires knowledge of how litter inputs will change with climate in the future. Such an analysis depends on understanding not 
only how climate influences the quantity and composition of litter produced by vegetation, but also how climate affects the abundances of litter decay products that can become part of the SOM reservoir.

Traditionally, researchers have assumed that litter chemistry converges during decomposition, i.e., initially distinct litter becomes more similar with advancing decomposition (Berg \& McClaugherty, 2008; Coûteaux, Bottner, \& Berg, 1995; Mathers, Jalota, Dalal, \& Boyd, 2007; Preston, Nault, \& Trofymow, 2009; Quideau, Graham, Oh, Hendrix, \& Wasylishen, 2005). This assumption implies that the chemistry of litter residuals can be predicted based upon the chemical composition of fresh litter and mass loss alone, independent of the climate under which decomposition occurs or its direct or indirect influence on microbial decomposers in the soil surface. Several recent studies, in contrast, have demonstrated that the conditions during decomposition can affect how litter chemistry changes during decomposition (Baumann et al., 2009; Glassman et al., 2018; Morrison et al., 2019; Wang et al., 2019; Wickings et al., 2011, 2012). The decomposition of initially identical plant litter at sites subjected to different land management practices, for example, resulted in chemically distinct litter residuals during late decomposition (Wickings et al., 2011, 2012). Similarly, the chemical composition of the residual litter following laboratory incubation depended on $\mathrm{N}$ fertilization prior to incubation, particularly in low-N litter types (Baumann et al., 2009). All such studies, however, were conducted under experimentally manipulated conditions. It therefore remains unclear if real-world climate change will have a sufficiently strong impact on environmental conditions (e.g., temperature and moisture) or ecosystem processes (e.g. nutrient availability and vegetation composition; Melillo et al., 2011; Philben et al., 2016) to change how litter chemistry is modified during decomposition. In our recent study of a boreal forest climate transect, we found that despite similar C chemistry of fresh needle litter across climate regions, depth profiles suggested that differences in SOM chemistry along the transect resulted from distinct organic matter inputs to these soils (Kohl et al., 2018). While some differences in the SOM chemistry could be attributed to different proportions of moss and vascular plant inputs, it remained unclear if part of these differences resulted from climate impacts on the decomposition of needle litter, which can contribute $30-53 \%$ to the SOM content of boreal forest soils (Clemmensen et al., 2013).

Climate can affect the litter decomposition process, and thus the composition of needle litter residuals, by changing the composition and metabolism of the microbial community (Glassman et al., 2018; Morrison et al., 2019). In a simple model, changes in needle litter chemistry can be conceptualized as the result of two processes: microbial catabolism, that is, the loss of litter components due to mineralization in support of microbial respiration; and microbial anabolism, which results in the addition of inputs of secondary microbial compounds (i.e., necromass, consisting of e.g., cell wall polymers, extracellular polymeric substances, and excreted protein) to decomposing litter (Fig. 1a). Therefore, there are two main ways in which climate may shape litter residual chemistry via altered microbial community composition and physiology. First, microbial decomposers excrete extracellular enzymes that break down plant polymers like lignin, cellulose, or protein into soluble monomers that are amenable to microbial metabolisms (Sinsabaugh et al., 
2011; Mooshammer et al., 2014). The catabolism of litter-degrading microorganisms therefore controls which litter components are preferentially degraded or preserved during decomposition (Moorhead \& Sinsabaugh, 2006; Fig 1b). Kinetic theory and laboratory experiments have shown that increasing temperatures can shift microbial substrate use towards compounds with higher activation energy (Biasi et al., 2005; Conant et al., 2011; Li et al., 2012), whereas $\mathrm{N}$ addition shifts substrate use towards the decomposition of more labile $C$ sources (Craine et al., 2007). In boreal forests, where a warmer climate can be associated with greater $\mathrm{N}$ availability (Philben et al., 2016), direct (temperature) and indirect (greater $\mathrm{N}$ availability) climate effects can represent counteracting effects on the residual needle litter chemistry. Second, microorganisms convert plant compounds into secondary microbial compounds, many of which can be more resistant to degradation than the initial plant compounds (Schimel \& Schaeffer, 2012) and constitute a large proportion of the organic matter pool in soils (Grandy \& Neff, 2008; Kindler et al., 2006; Miltner et al., 2009; Schurig et al., 2012). Climate induced changes to the composition or physiology of the decomposer community have the potential to change its overall anabolism, i.e. how the community allocates litter $\mathrm{C}$ towards different intra- and extracellular compounds. These changes in anabolism can influence the chemical composition of needle litter residues if they change the composition of microbial necromass (Fig. 1c) or the amount of secondary microbial compounds produced per substrate consumed (Fig. 1d; Schimel \& Schaeffer, 2012).

Further, climate changes that shift fungi:bacteria ratios may affect the chemical composition of needle litter residuals through changes in selective decomposition (Fig 1b), necromass composition (Fig. 1c), and quantity of necromass added to litter per litter mass lost (Fig. 1d). Such changes in fungi:bacteria ratios with climate are likely given that the warming of boreal forests can be associated with greater $\mathrm{N}$ availability (Björn Berg \& Meentemeyer, 2002; Philben et al., 2016), which can in turn lead to a decrease in fungi:bacteria ratios (Grosso et al., 2016; Högberg et al., 2007). Fungi and bacteria differ in both biomass composition (e.g. cell wall structures (Kögel-Knabner, 2002)) and metabolic capabilities (Strickland \& Rousk, 2010). Fungi are believed to express a broader set of extracellular enzymes (Schneider et al., 2010, 2012) and fungal biomass has a greater C:N ratio (Sterner \& Elser, 2002) which can coincide with a higher C use efficiency (CUE) (Keiblinger et al., 2010; Waring et al., 2013). This is consistent with model simulations and experimental results showing that microbial communities with high fungi:bacteria ratios sequestrate more litter $\mathrm{C}$ into (non-living) SOC than communities with low fungi:bacteria ratios (Malik et al., 2016; Waring et al., 2013). Generating a better understanding of how fungi:bacteria ratios influence the litter decomposition process, and if this influence is dominated by selective decomposition or distinct necromass inputs, is an important step towards understanding the effect of microbial community structure on SOM formation and chemistry.

One tool useful for linking organic matter chemistry and microbial metabolism is stable carbon isotope $\left(\delta^{13} \mathrm{C}\right)$ analysis. Due to isotopic fractionation during biosynthesis (Fogel \& Cifuentes, 1993), $\delta^{13} \mathrm{C}$ values vary among distinct plant compounds, such that the $\delta^{13} \mathrm{C}$ values of distinct compound classes in the same plant tissues differ by 10-14\%o (B Glaser, 2005). As a general trend, more labile compounds exhibit higher $\delta^{13} \mathrm{C}$ values than classes of compounds 
typically considered to turn over more slowly (e.g. pectin $>$ hemicellulose $>$ amino acids and sugars $>$ cellulose > lignin > lipids/waxes; Glaser, 2005). During litter decomposition, the $\delta^{13} \mathrm{C}$ value of the residual litter changes. The direction and degree of this change, however, differs among litter types, representing the accumulation of ${ }^{13} \mathrm{C}$-enriched and ${ }^{13} \mathrm{C}$-depleted compound classes (Preston et al., 2009). Similarly, the $\delta^{13} \mathrm{C}$ value of microbial biomass $\left(\delta^{13} \mathrm{C}_{\text {biomass }}\right)$ reflects the $\delta^{13} \mathrm{C}$ of the substrates that a microorganism has consumed and the isotope fractionation associated with its metabolism (Blair et al., 1985; Lehmeier, Ballantyne, Min, \& Billings, 2016). The $\delta^{13} \mathrm{C}$ of biomarkers specific to living microbial biomass, like phospholipid fatty acids (PLFA), can be used

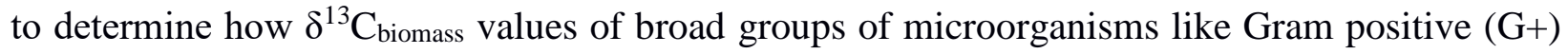
and Gram negative (G-) bacteria or fungi vary among samples. Such measurements provide a tool for making inferences about the $\mathrm{C}$ sources used by different microbial groups (Abraham et al., 1998; Cifuentes \& Salata, 2001; e.g., Coffin et al., 1990) and microbial biomass contributions to SOM formation (Kohl et al., 2015).

Here, we measured the abundance and $\delta^{13} \mathrm{C}$ values of microbial biomarkers at the litter layer to investigate how a warmer climate will alter patterns of litter decomposition and whether such impacts are caused by changes to microbial necromass input or to microbes' selective removal (i.e., mineralization) of litter components. Our study was conducted in the Newfoundland and Labrador Boreal Ecosystem Latitudinal Transect (NL-BELT), a well-constrained climate transect of mesic balsam fir forests in Atlantic Canada. In this transect, warmer sites served as a scenario for how colder transect sites will develop in a future warmer and wetter climate (Table 1). With this approach, we address three hypotheses about how climate warming, as simulated in the NL-BELT, affects the litter decomposition process.

(1) A warmer and wetter climate promotes lower fungal relative to bacterial abundances in, and thus differences in the metabolic capacity of, the decomposer community.

(2) Through decreased fungi:bacteria ratios, a warmer and wetter climate promotes modifications of litter chemistry during decomposition that are distinct from those in a cooler climate.

(3) Regionally distinct litter chemistry results from some combination of differences in the amount or composition of secondary microbial compounds in decaying litter (i.e., variation in the consequences of CUE and/or microbial anabolism), rather than variation in the selective degradation of litter constituents (i.e., variation in the consequences of microbial altered catabolism).

\section{Materials and methods}

\subsection{Field sites}

The NL-BELT climate transect is located in western Newfoundland and southeastern Labrador (Canada; Supporting Information S1). Detailed descriptions of the transect have been published previously (Kohl et al., 2015, 2018; Laganière, Podrebarac, Billings, Edwards, \& 
Ziegler, 2015; Ziegler et al., 2017). Within the NL-BELT transect, more southern sites are characterized by greater mean annual temperatures (MAP, $5.2{ }^{\circ} \mathrm{C}$ ), and precipitation (MAP, 1575 $\mathrm{mm})$ compared to more northern sites $\left(0.0^{\circ} \mathrm{C}\right.$ MAT, $1040 \mathrm{~mm}$ MAP; Table 1$)$. These differences in temperature and precipitation are in the range of the climatic changes predicted for this region until the end of the $21^{\text {st }}$ century (Price et al., 2013; van Oldenborgh et al., 2013), such that the southernmost sites of the transect provide a realistic scenario for the future development of its northernmost sites over the current century. Annual water availability, defined as MAP minus potential evapotranspiration, was higher in more southern $\left(897 \mathrm{~mm} \mathrm{a}^{-1}\right)$ than more northern sites $\left(644 \mathrm{~mm} \mathrm{a}^{-1}\right)$. However, the southernmost transect sites exhibited similar soil moisture as the northernmost ones (Supporting Information S2) suggesting water availability is similar across these regions despite the differences in precipitation. The southern sites, furthermore, exhibited greater nitrogen $(\mathrm{N})$ concentrations in foliage, litter, and soils, likely due to accelerated $\mathrm{N}$ cycling (Philben et al., 2016).

For this study we used three climate regions of the transect, which will be referred to as the 'cold', 'mid', and 'warm' region. In each region, the transect consists of 3 field sites that are located within mature balsam fir (Abies balsamea) stands on well drained podzolic soils (Table 1). The sites exhibit no signs of previous harvest or afforestation, and therefore represent incarnations of $A$. balsamea forests that have developed under distinct climate regimes. At each site, 3 circular long term study plots $10 \mathrm{~m}$ in diameter ( 27 plots in total) were established previously (Laganière et al., 2015).

\subsection{Surface soil phospholipid fatty acid (PLFA) analysis}

To study how the abundance of major microbial groups and their metabolic strategies $(\mathrm{C}$ sources and/or $\mathrm{C}$ allocation) varied among transect sites, we measured the composition and $\delta^{13} \mathrm{C}$ values of phospholipid fatty acids (PLFAs) in the litter layer of each transect site, that is the top 1$2 \mathrm{~cm}$ of the forest floor consisting of recognizable plant material. All samples were collected in June 2011. For each plot, three pieces $(20 \times 10 \mathrm{~cm})$ were cut from the organic layer after removing all living vegetation, and each piece was further cut into two $10 \times 10 \mathrm{~cm}$ subsamples. We then manually separated the litter layer $\left(\mathrm{O}_{\mathrm{i}}\right.$ or $\mathrm{L}$ horizon), i.e., the top $1-2 \mathrm{~cm}$ of organic matter consisting of recognizable plant remains, from the deeper organic layer. The litter layer samples from each plot were then combined into two composite samples for chemical and microbiological analysis, resulting in two sets of 27 samples. One set of samples, intended for PLFA analysis, was stored on ice in the field, frozen at the end of each field day, and freeze dried before long-term storage. The freeze-dried samples were then ground with mortar and pestle before PLFA extraction. The other set, intended for chemical analysis was kept cold $\left(4^{\circ} \mathrm{C}\right)$ during the field campaign and then air-dried and ball-milled (Retsch M200) prior to analysis.

Bulk soil analysis $\left(\% \mathrm{C}, \% \mathrm{~N}, \delta^{13} \mathrm{C}_{\text {bulk }}\right)$ was conducted by elemental analysis isotope ratio mass spectrometry (EA/IRMS, Carlo Erba NA1500 Series II, Thermo DeltaV Plus). The instrument precision ( 2 standard deviations $(\sigma)$ ) for $\delta^{13} \mathrm{C}$ was $<0.5 \%$ with a mean offset $<0.2 \%$ o to certified values (Kohl et al., 2015). The PLFA analysis was conducted as outlined in the supporting 
information of Kohl et al., (2015), which developed based on several previous methods (Abrajano, Murphy, Fang, Comet, \& Brooks, 1994; Cooke, Talbot, \& Farrimond, 2008; Cooke, Talbot, \& Wagner, 2008; Frostegård, Tunlid, \& Baarth, 1993; White \& Ringelberg, 1998; Ziegler, White, Wolf, \& Thoma, 2005). Briefly, samples were extracted with dichloromethane (DCM) / methanol $(\mathrm{MeOH}) /$ phosphate buffer (1:2:0.8). Phase separation was induced by adding DCM and phosphate buffer and the lower, organic phase was collected, dried, and taken up in DCM. Phospholipids were isolated by solid phase extraction over a silica phase. After eluting neutral and glycolipids with DCM and acetone, phospholipids were eluted with $\mathrm{MeOH}$ and DCM:MeOH:water (3:5:2). Phospholipids were then converted to the fatty acid methyl esters (FAMEs) by alkaline methanolysis and analysed by gas chromatography flame ionization detection (Agilent 6890A) for quantification and gas chromatography isotope ratio mass spectrometry for stable isotope analysis (Agilent 6890N interfaces to Thermo Delta V+ IRMS via a Thermo GC-C III). The precision of this method $(2 \sigma)$ was $<0.6 \%$ and the accuracy was $<0.3 \%$. Selected samples were further analyzed by gas chromatography mass spectrometry (Agilent 6890N GC, Agilent 5975C MS) to confirm peak identifications. We analyzed a total of 26 samples (one from each transect plot; one sample was lost during analysis, $n=8-9$ per region).

In each sample, we quantified 25 individual PLFA, which were assigned to six groups (Gram positive (G+) bacteria, Gram negative (G-) bacteria, actinobacteria, fungi, other eukaryotes, and non-specific; Supporting Information SI3). Based on this assignment, we calculated the molar ratio of fungal to bacterial (sum of $\mathrm{G}+, \mathrm{G}-$, and actinobacterial) PLFA (F:B). We report $\delta^{13} \mathrm{C}$ of 10 individual PLFA per sample after correcting for methanol-derived C. Two of these PLFA are specific to G+ bacteria (i15:0, a15:0), four are specific to G- bacteria (16:1 $17,18: 1 \omega 7$, cy17:0,

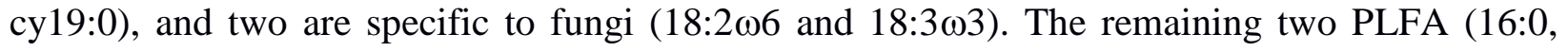
18:119) occur widespread in both fungi and bacteria (Frostegård et al., 2010; Grogan \& Cronan, 1997; Ruess \& Chamberlain, 2010). To account for differences in soil $\delta^{13} \mathrm{C}$ values among transect sites and to study microbial biomass $\delta^{13} \mathrm{C}$ values relative to the available substrates, we calculated the differences between stable $\mathrm{C}$ isotope values of PLFA $\left(\delta^{13} C_{P L F A}\right)$ and the bulk $\delta^{13} \mathrm{C}$ value of the litter layer from which they were extracted $\left(\delta^{13} C_{\text {bulk }}\right)$, such that $\Delta^{13} C_{P L F A \text {-bulk }}$ was defined as $\delta^{13} C_{P L F A}-\delta^{13} C_{\text {bulk }}$ (we use $\Delta^{13} C_{a-b}$ to refer to differences between measured stable isotope values and $\varepsilon_{\mathrm{a}-\mathrm{b}}$ to refer to derived enrichment factors and isotope effects in models).

\subsection{Changes in litter chemistry during decomposition}

To directly assess if climate affects changes in litter chemistry during decomposition, we conducted a 1-year litter decomposition experiment at each transect site. The experiments were designed to capture the sum of direct climate effects (i.e., temperature) and indirect climate effects mediated through changes in litter composition (i.e., greater $\% \mathrm{~N}$ in fresh litter from warmer regions). We therefore exposed local litter from each transect region to decomposition under the local climate. We did not attempt to distinguish between these direct and indirect effects in the current study. 
Needle foliage from the three sites in each region was collected from mature balsam forests trees (>10 cm dbh) in late August 2012, corresponding with the end of the growing season. The needles from each region were then mixed and 18 litter bags per region were each filled with $5 \mathrm{~g}$ needles (equivalent air-dried weight). The litterbags measured $20 \times 20 \mathrm{~cm}$ and were constructed using woven polypropylene fabric (Lumite style 6065400) with $0.25 \mathrm{~mm}$ x $0.5 \mathrm{~mm}$ mesh (Trofymow \& CIDET Working Group, 1998). Six such litterbags, containing the litter from the respective region, were placed at each of the nine field sites between late October and midDecember 2012. The litterbags were pinned to the top of the forest floor with wire to ensure contact to the soil and retrieved after 11-12 months. Given the relatively large size of the litterbags compared to the amount of litter, we expect that the microclimate inside the litterbags fell within the range of natural environments at each site, although the environment within the bags experienced a delay in both wetting and drying conditions occurring in situ. Litter from the warm and mid regions was retrieved slightly earlier than litter from the cold region, such that litter in all regions had undergone similar mass loss at the time of retrieval. The material in each retrieved litterbag was visually inspected to confirm the absence of extraneous material before further processing. Mass loss was determined by drying at $55{ }^{\circ} \mathrm{C}$ for $48 \mathrm{~h}$, and the samples were homogenized using a Wiley Mini Mill 3383-L20 (Thomas Scientific; mesh size 60) for further analyses. Elemental concentrations $(\% \mathrm{C}, \% \mathrm{~N})$ and bulk $\delta^{13} \mathrm{C}$ values were analyzed by EA-IRMS as described above on 18 replicate litterbags per region $(n=54)$ as well as duplicates of the initial litter from each region $(n=6)$. Carbon loss was calculated based on $\% \mathrm{C}$ and mass loss. Based on these results we estimated the stable isotope value of the lost litter fraction by mass balance according to Eq. 1, where $f_{\text {lost }}$ represents the $\mathrm{C}$ loss as a fraction of the initial litter $\mathrm{C}$. This estimate assumes that any introduction of extraneous $\mathrm{C}$, e.g. with the ingrowth of fungal hyphae, was negligible.

284 285

(1) $\delta^{13} C_{\text {lost }}=\frac{\delta^{13} C_{\text {initial }}-\delta^{13} C_{\text {residual }}\left(1-f_{\text {lost }}\right)}{f_{\text {lost }}}$

We furthermore quantified the stable isotope fractionation effect $\varepsilon_{r L}$ that characterizes the enrichment of ${ }^{13} \mathrm{C}$ in residual litter, which was defined as

$$
\text { (2) } \varepsilon_{\mathrm{rL}}=\left(\delta^{13} \mathrm{C}_{\text {residual }}-\delta^{13} \mathrm{C}_{\text {initial }}\right) \cdot \zeta \text {, }
$$

where $\zeta=\frac{1-f_{\text {lost }}}{f_{\text {lost }}}$

Cross polarization, magic-angle spinning solid state nuclear magnetic resonance (CP-MAS NMR; Barron et al., 1980) analysis was conducted as described previously (Kohl et al., 2018). For each region, we analyzed one sample of initial litter and three samples of decomposed litter that were pooled from the six replicate litter bags retrieved from each site. CP-MAS NMR measurements were conducted using a Bruker AVANCE II $600 \mathrm{MHz}$ instrument with a MASHCCND probe. Samples were run at $600.33 \mathrm{MHz}\left({ }^{1} \mathrm{H}\right)$ or $150.96 \mathrm{MHz}\left({ }^{13} \mathrm{C}\right)$ and spun at 20 $\mathrm{kHz}$ at $298 \mathrm{~K}$. NMR spectra were analyzed after baseline subtraction and normalization to a constant total integrated area. Spectra were further deconvoluted based on a 19 peak model using 
the software DM Fit (Massiot et al., 2002) and peaks were grouped into 8 functional groups (alkyl$\mathrm{C}$, methoxy-C, O-alkyl-C, di-O-alkyl-C, aromatic C, phenolic C, carboxy-C) based on Wilson (1987) and Preston et al. (2009). Based on these results, we calculated the change in the relative abundance of each group relative to its initial abundance (Eq. 2).

(3) $\%_{\text {change }}=100 \cdot\left(\frac{\text { abundance in residual litter }}{\text { abundance in initial litter }}-1\right)$

\subsection{Data analysis}

To test whether litter layer samples from the distinct transect regions differed in the biomass of different microbial groups, and/or microbial metabolic strategies (Hypothesis 1), we applied a one-way analyses of variance (ANOVA) and Tukey post-hoc tests to evaluate if the overall PLFA concentration, the relative abundance of PLFA associated with microbial groups, and the weighted mean $\triangle^{13} C_{P L F A-b u l k}$ values differed among transect regions. We furthermore tested if $\mathrm{C}: \mathrm{N}$ ratios of the litter layer and local litterfall (data from Kohl et al., 2018), the ratio of fungal to bacterial PLFA, and $\triangle^{13} C_{P L F A-b u l k}$ values covaried using Pearson's correlation tests.

Differences in weighted mean $\Delta^{13} C_{P L F A-b u l k}$ values among transect regions may indicate differences in the enrichment or depletion of ${ }^{13} \mathrm{C}$ in biomass relative to bulk litter $\left(\varepsilon_{\text {biom-bulk }}\right)$ in one or more microbial groups, but can also result from changes in the relative abundance of microbial groups with contrasting $\varepsilon_{\text {biom-bulk }}$ values. For example, a decrease in fungi:bacteria ratio can cause a more depleted weighted mean $\Delta^{13} C_{P L F A-b u l k}$ value even if the $\varepsilon_{\text {biom-bulk }}$ values of both fungi and bacteria remain constant. We therefore tested if the $\Delta^{13} C_{P L F A-b u l k}$ values of each individual PLFA varied among climate regions by applying Kruksal-Wallis tests and Nemenyi post-hoc tests. We furthermore tested for covariance of $\mathrm{N}$ availability and microbial $\mathrm{C}$ isotope values by applying Spearman's correlation test between C:N ratios of SOM and the $\triangle^{13} C_{P L F A-b u l k}$ values of individual PLFA. We chose to use these non-parametric tests because they are less sensitive to outliers than the parametric tests we used to compare aggregated measures.

Moreover, we applied one-way analyses of variance (ANOVAs) to test if changes in the relative abundance of functional groups during litter decomposition (\% $\%_{\text {change }}$ ) differed between transect regions (Hypothesis 2). We furthermore tested if daily litter mass loss rates, total mass loss, and total $\mathrm{C}$ loss differed between transect regions by applying a mixed effects model with region as a fixed effect and site within region as a random effect. The same mixed effect model was applied to test if ${ }^{13} \mathrm{C}$ enrichment during litter decomposition $\left(\varepsilon_{r L}\right)$ differed between transect regions.

To assess the degree to which differences in anabolic and catabolic metabolism contributed to distinct litter residual chemistry across climate regions (Hypothesis 3 ), we compared differences

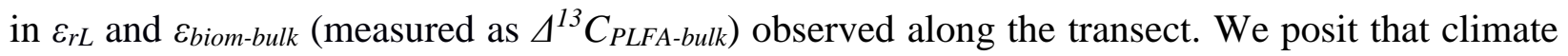
can alter the chemical composition of residual litter through three distinct mechanisms, that is (1) by influencing microbial substrate use patterns (Fig 1b); (2) by changing microbial C allocation 
(Fig 1c); and (3) through changes in the proportion of substrate converted into microbial necromass and retained in the residual litter (Fig 1d). These mechanisms are not mutually exclusive.

We explore how these three mechanisms affected $\varepsilon_{r L}$ and $\varepsilon_{\text {biom-bulk }}$ based on the litter decomposition model depicted in Fig 1. In this model, microbial decomposers consume a fraction of the initial amount litter $\mathrm{C}\left(f_{\text {cons }}\right)$. The stable isotope value of these consumed substrates $\left(\delta^{13} C_{\text {subs }}\right.$, not measured) can be distinct from the bulk litter $\left(\delta^{13} C_{b u l k}\right)$ if microorganisms would preferentially degrade some litter components relative to others. We therefore use the difference $\varepsilon_{\text {subs-bulk }}=$ $\delta^{13} \mathrm{C}_{\text {subs }}-\delta^{13} \mathrm{C}_{\text {bulk }}$ as a measure of microbial substrate use patterns. Of these substrates, a fraction $\left(C U E_{c}\right)$ is converted into secondary microbial compounds that are added back to the remaining litter, while the remaining fraction $\left(1-\mathrm{CUE}_{\mathrm{c}}\right)$ is lost as respired $\mathrm{CO}_{2}$ or leached as dissolved organic C. The isotopic composition of these secondary microbial inputs $\left(\delta^{13} C_{b i o m}\right)$ is different from $\delta^{13} \mathrm{C}_{\text {substrate }}$ due to stable isotope fractionation during biosynthesis, which depends on the proportions in which distinct compound classes are produced along with other properties of the microbial anabolism. We therefore use the difference $\varepsilon_{\text {biom-subs }}=\delta^{13} \mathrm{C}_{\text {biom }}-\delta^{13} \mathrm{C}_{\text {susbs }}$ as a measure of microbial $\mathrm{C}$ allocation and microbial anabolism in general.

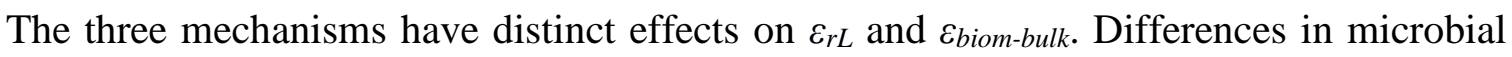
substrate use (i.e, $\varepsilon_{s u b s-b u l k}$ ) affect $\varepsilon_{r L}$ and $\varepsilon_{b i o m-b u l k}$ in opposite directions (higher $\varepsilon_{s u b s-b u l k}$ values decrease $\varepsilon_{r L}$ but increase $\varepsilon_{b i o m-b u l k}$ ), leading to a negative slope between $\varepsilon_{r L}$ and $\Delta^{13} C_{P L F A-b u l k}$. Differences in microbial $\mathrm{C}$ allocation (i.e., Ebiom-subs), in contrast, affect $\varepsilon_{r L}$ and $\varepsilon_{b i o m-b u l k}$ in the same direction (higher $\varepsilon_{b i o m-s u b s}$ values increase both $\varepsilon_{r L}$ and $\varepsilon_{b i o m-b u l k}$ ), leading to a positive slope between $\varepsilon_{r L}$ and $\triangle^{13} C_{P L F A-b u l k}$. Finally, changes to the $C U E_{c}$ can further increase or decrease $\varepsilon_{r L}$ depending on the initial values of $\varepsilon_{\text {biom-subs }}$ and $C U E_{c}$, and can thus change the slope between $\varepsilon_{r L}$ and $\Delta^{13} C_{P L F A-}$ SOC. The three types of climate-induced changes to litter decomposition have additive effects on $\varepsilon_{r L}$ and $\varepsilon_{\text {biom-bulk, }}$, as shown in eqs. 4 and 5 , where $\mathrm{d} \varepsilon_{\text {biom-bulk, }}, \mathrm{d} \varepsilon_{r L}, \mathrm{~d} \varepsilon_{\text {subs-bulk, }}, \mathrm{d} \varepsilon_{\text {biom-subss }}$, and $\mathrm{d} C U E_{C}$ represent the instantaneous changes in $\varepsilon_{\text {biom-bulk, }}, \varepsilon_{r L}, \varepsilon_{\text {subs-bulk, }} \varepsilon_{\text {biom-subs, }}$ and $C U E_{C}$. A derivation of these equations is provided in Supporting Information S4.

$$
d \varepsilon_{\text {biom-bulk }}=d \varepsilon_{\text {subs-bulk }}+d \varepsilon_{\text {biom-subs }}
$$

$$
d \varepsilon_{r L}=-d \varepsilon_{\text {subs-bulk }}+\frac{C U E_{c}}{1-C U E_{c}} \cdot d \varepsilon_{\text {biom-subs }}+\frac{1}{\left(1-C U E_{c}\right)^{2}} \cdot \varepsilon_{\text {biom-subs }} \cdot d C U E_{c}
$$

As shown in Supporting Information $\mathrm{S} 4$, the ratio $\mathrm{d} \varepsilon_{r L} / \mathrm{d} \varepsilon_{\text {biom-bulk }}$ is constrained to -1 if climate alters only microbial substrate use patterns (Fig. 1b) and to CUE $/\left(1-C U E_{C}\right)$, which is always positive, if climate alters only microbial $\mathrm{C}$ allocation (Fig. 1c). A positive slope between $\varepsilon_{r L}$ and $\varepsilon_{b i o m-b u l k}$ (and thus between $\varepsilon_{r L}$ and $\Delta^{13} C_{P L F A-b u l k}$ ) therefore provides evidence in support of our Hypothesis 3 that climate primarily affects the composition of residual litter through changes in the abundance or composition of microbial necromass inputs (Figs. 1c and 1d) rather than changes in substrate use patterns (Fig. 1b). We therefore evaluated Hypothesis 3 by testing for a 
371 linear regression between $\varepsilon_{r L}$ and the weighted mean $\Delta^{13} C_{P L F A-b u l k}$ values using Pearson's correlation coefficient. In addition, we also tested for correlations between $\varepsilon_{r L}$ and the $\Delta^{13} C_{P L F A-b u l k}$ values of all individual PLFA to ensure that such a regression was not merely the results of changes in community composition (as described above).

We used the same isotope mass balance model to estimate the differences in $\varepsilon_{\text {subs-bulk, }}$, cbiomsubs, and $C U E_{C}$ between transect regions, i.e., to estimate how large of difference in $\delta^{13} \mathrm{C}$ values relative to bulk litter (Fig. 1b), biomass $\delta^{13} \mathrm{C}$ relative to the substrates (Fig. 1c), or necromass production per substrate consumed (Fig 1d) between the transect regions was required to explain the observed data. As we did not detect significant differences in $\varepsilon_{r L}$ or $\Delta^{13} C_{\text {PLFA-bulk between the }}$ mid and warm regions, these two regions were combined for this analysis and estimated the

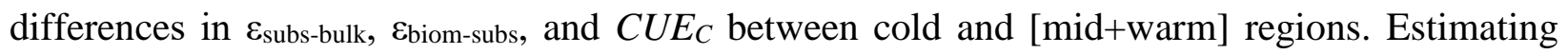
these differences further required assumptions about two parameters not directly measured, i.e., the initial $C U E_{C}$ and $\varepsilon_{b i o m-s u b s}$ values. We assumed values of 0.3 or 0.6 for $C U E_{C}$ and $0 \%$, $2 \%$, or

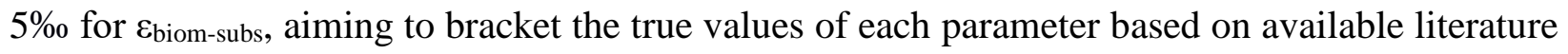
data. Further details on these estimates are provided in Supporting Information S5.

All statistical analyses were conducted using the statistical programming environment $\mathrm{R}$ version 3.2.3 (R Development Core Team, 2015). All stated uncertainties indicate one standard deviation unless identified otherwise.

\section{Results \\ 3.1. Microbial community composition and $\delta^{13} C_{P L F A}$ values}

Microbial biomass and microbial community composition. Total PLFA concentrations, a proxy for microbial biomass, did not differ in litter layer samples from the different transect regions (Fig. 2a, Supporting Information S3). Climate, however, had strongly influenced microbial community composition, as evidenced by strong contrasts in the proportions of PLFA associated with distinct microbial groups. From the cold to warm region, the proportions of PLFA associated with fungi and non-fungal eukaryotes decreased, while proportion of PLFA associated with G+ bacteria, G- bacteria, and actinobacteria increased (Fig 2b). Consequently, the ratios of fungal:bacterial PLFA ratios (F:B) decreased by $43 \%$ (95\% confidence interval: 18-68\%) from cold to the warm region, from $1.02 \pm 0.25$ to $0.58 \pm 0.24(\mathrm{~F}=12.1, \mathrm{p}<0.001)$. F: $\mathrm{B}$ ratios were correlated with the $\mathrm{C}: \mathrm{N}$ ratio of the litter layer $(\mathrm{R}=0.46, \mathrm{p}=0.018)$ and of litterfall $(\mathrm{R}=0.56$, p=0.003; Fig. 3a).

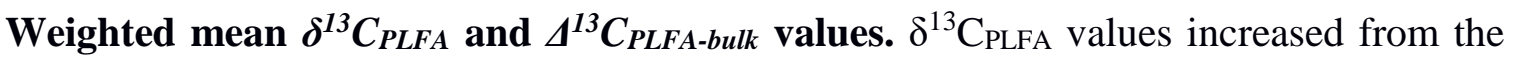
cold to the warm region, both in absolute terms $\left(\delta^{13} \mathrm{CPLFA}_{\mathrm{PA}}\right)$ and relative to the bulk soil ( $\Delta^{13} \mathrm{C}_{\text {PLFA- }}$

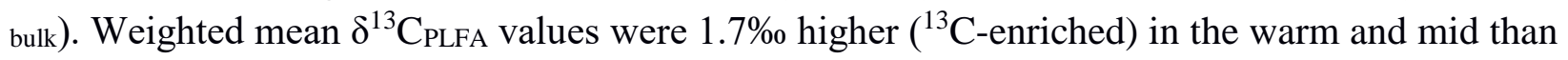
in the cold region (Fig 4b; F=19.7, p<0.001), a difference significantly larger than among bulk litter layer values $\left(\delta^{13} \mathrm{C}_{\text {bulk }}\right.$ ), which were $0.6 \%$ higher in the warm than in the cold region (Fig $4 \mathrm{a}$;

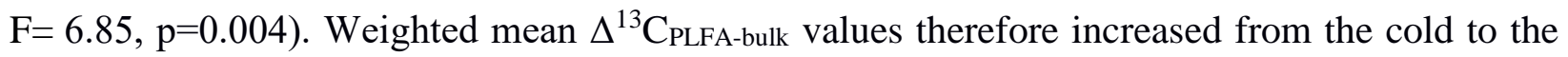


warm regions, with $\delta^{13} \mathrm{C}$ values of PLFA being $3.4 \pm 0.8 \%$ lower than bulk SOC in the cold region, and only $2.3 \pm 0.3 \%$ lower than SOC in the warm region (Fig $4 \mathrm{c} ; \mathrm{F}=9.07, \mathrm{p}=0.001$ ). Weighted

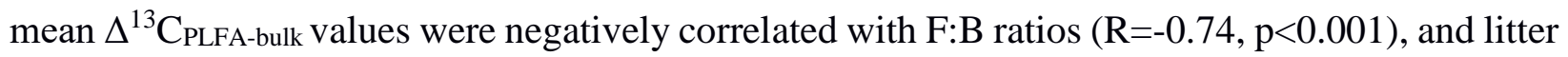
layer $\mathrm{C}: \mathrm{N}$ ratios $(\mathrm{R}=-0.47, \mathrm{p}=0.013$; Fig. 3b, 3c).

$\Delta^{13} C_{P L F A-b u l k}$ values of individual PLFA. $\Delta^{13} C_{P L F A-b u l k}$ values of individual PLFA varied strongly throughout the dataset $(-10.6$ to $+3.3 \%$ ), which is consistent with previous studies (Churchland et al., 2013; Cusack et al., 2011; Kohl et al., 2015). $\Delta^{13} C_{P L F A-b u l k}$ varied systematically among individual PLFA as well as among samples (Fig 4). Most importantly, $\Delta^{13} C_{P L F A-b u l k}$ values were distinct by the identity of the individual PLFA, i.e., the same PLFA was enriched or depleted relative to other PLFA or SOC in all samples. Fungal PLFA exhibited more negative $\Delta^{13} C_{P L F A-b u l k}$ values (-7.9 to $-3.1 \%$ ) than G- bacterial PLFA $(-0.9$ to $+0.7 \%$ ) and $\mathrm{G}+$ bacterial PLFA (-0.0 to $+2.4 \%$ ) (Fig 5).

Individual PLFA in the warm region had equal or higher $\Delta^{13} C_{P L F A-b u l k}$ values than the same PLFA in the cold region (Fig 5). Among the ten individual PLFA analyzed, five (i15:0, a15:0, 16:0, 16:1, and 18:3; all $\left.\chi^{2}>7.49, \mathrm{p}<0.024\right)$ exhibited 1.0 to $1.9 \%$ higher $\Delta^{13}$ CPLFA-bulk in the warm $^{2}$ region than in the cold region (Table 2). The $\Delta^{13} C_{P L F A-b u l k}$ of four of these PLFA decreased with the $\mathrm{C}: \mathrm{N}$ ratio of the litter layer (Table 2; all $\rho<-0.43, \mathrm{p}<0.033$ ). However, no consistent trends in $\triangle^{13} C_{\text {PLFA-bulk }}$ were observed for PLFA specific to distinct source organism groups (i.e., fungi, Gbacteria, G+ bacteria; Fig 5).

\subsection{Litterbag experiment}

Initial litter chemistry. Litter \%C was similar in all transect regions (49.7 to 51.9\%; Supporting Information S6), as were initial $\delta^{13} \mathrm{C}$ values $(-31.3$ to $-30.8 \%$ ). Litter $\% \mathrm{~N}$ increased from cold to warm regions, with litter containing $0.96 \pm 0.02,1.08 \pm 0.01$, and $1.23 \pm 0.01 \% \mathrm{~N}$ in the cold, mid, and warm region, respectively $(\mathrm{F}=353, \mathrm{p}<0.001)$. Initial $\delta^{15} \mathrm{~N}$ values also increased from the coldest to the warmest region $(-5.7 \pm 0.1 \%,-2.5 \pm 0.0 \%$, and $-0.8 \pm 0.2 \%$, respectively; $\mathrm{F}=787, \mathrm{p}<0.001)$.

While the initial litter used for the litterbag experiment differed in nutrient concentrations $(\% \mathrm{~N})$, the $\mathrm{C}$ chemistry (based on NMR spectra) was highly similar (Supporting Information S7). Initial litter NMR spectra were dominated by a large double peak in the O-alkyl region (72 and 75 ppm), representative of carbohydrates (Fig. S3a). Further peaks occurred in the alkyl (26, 30, and 33 ppm; plant waxes and lipids), in the methoxy (56 ppm, common in lignin), O-alkyl (62 and 65 ppm; common in carbohydrates and peptides), di-O-alkyl (98 and 105 ppm; carbohydrates), aromatic (116 and $131 \mathrm{ppm}$ ), phenolic (145 and $156 \mathrm{ppm}$ ), and carboxyl (174 ppm) regions of the spectra (assignment based on Kögel-Knabner et al. (1992), Kögel et al. (1988), Zech et al. (1987) and other sources after Preston et al. (2000). The spectra of initial litter from all three regions were highly similar (Fig. S3a) which is consistent with our previous analysis of three years of litterfall from these sites, in that samples of 'fresh' needle litter from distinct regions differ in nutrient concentrations, but do not exhibit distinct NMR spectra (Kohl et al., 2018). Furthermore, the variance in the proportions of functional groups among samples of initial litter from different 
regions was equal or lower than the variance among replicate litterbags retrieved from different sites within the same region after decomposition (Levene-test, all $\mathrm{F}<1.32, \mathrm{p}>0.335$ ). This shows that difference in the spectra of initial litter chemistry across the three regions were negligibly small compared to differences in litter chemistry acquired during litter decomposition.

Mass loss. Mass loss rates of local needle foliage increased from $29.8 \pm 1.8 \% \mathrm{yr}^{-1}$ in the cold region to $35.6 \pm 4.6 \% \mathrm{yr}^{-1}$ in the warm region (Fig $6 \mathrm{a} ; \mathrm{F}=20.2, \mathrm{p}<0.001$ ). The total mass loss, however, varied only slightly $(29.7 \pm 0.4 \%, 28.3 \pm 0.4 \%$, and $33.5 \pm 1.0 \%$ in the cold, mid, and warm regions; Fig 6b) as slower mass loss in the northernmost region was compensated by slightly longer exposure (12 months) compared to the two more southern regions (11 months). C losses were similar to overall mass losses $(29.5 \pm 1.5 \%, 25.6 \pm 1.9 \%$, and $32.3 \pm 1.6 \%$, respectively; Fig $6 \mathrm{c})$. The total mass and $\mathrm{C}$ loss from the transect regions therefore varied by $<25 \%$.

Chemical changes associated with litter decomposition. Litter \%C increased slightly during decomposition to 50.9 to $51.9 \%$. Litter $\% \mathrm{~N}$ increased to $1.63 \pm 0.06,1.69 \pm 0.07$, and 1.95 $\pm 0.14 \%$ in the cold, mid, and warm region, respectively $(\mathrm{F}=51.8, \mathrm{p}<0.001)$. These values indicate litter $\mathrm{N}$ increased in absolute terms during decomposition such that, in spite of mass loss, litter contained a greater amount of $\mathrm{N}$ after decomposition in all sites. This has been observed previously in litter from multiple boreal species (Moore et al., 2010). This net increase in litter N with decomposition decreased from cold to warm regions, and the retrieved litterbags contained 119.3 $\pm 4.9 \%, 112.9 \pm 4.4 \%$, and $+105.4 \pm 3.1 \%$ of the initial $\mathrm{N}$ across these regions, respectively $(\mathrm{F}=$ $72.7, \mathrm{p}<0.001)$.

Needle litter from all transect regions exhibited some common changes in NMR spectra during decomposition (Figs. 7, Supporting Information S7, S8), including a decrease in the relative proportion of phenolic $\mathrm{C}$ abundance and an increase in carbonyl proportion (Figs. 7). In addition to these general changes, we also observed changes specific to the three field regions. Litter in the cold and mid regions, but not in the warm region, exhibited a significant increase in the proportions of alkyl C (Figs. 7). This increase occurred in particular at 20-25 ppm and $38 \mathrm{ppm}$, i.e., separate from the main alkyl peaks (Fig Supporting Information S7). The relative abundance of O-alkyl C and di-O-alkyl $\mathrm{C}$, in contrast, decreased in the mid and cold regions, but not the warm region. The methoxy $\mathrm{C}$ peak at $56 \mathrm{ppm}$ showed a decreasing trend in the cold region and an increasing trend in the warm region (Figs. 7). The residual litter from colder regions therefore exhibited a greater relative abundance of alkyl-C and a lower relative abundance of $\mathrm{O}$-alkyl, di-O-alkyl, and methoxy $\mathrm{C}$ compared to residual litter from warmer regions (Figs. 7).

Stable $\mathbf{C}$ isotope ratios. In the cold region, the $\delta^{13} \mathrm{C}$ values of litter did not change significantly during decomposition. Therefore, the initial, residual, and the lost litter fractions had similar $\delta^{13} \mathrm{C}$ values (Fig 8). In the mid and warm regions, residual litter exhibited increased $\delta^{13} \mathrm{C}$ values relative to initial litter. The isotopic enrichment effects in residual litter $\left(\varepsilon_{r L}\right)$ were $0.11 \pm 0.27 \%$ o $0.89 \pm 0.45 \%$, and $0.82 \pm 0.39 \%$ in the cold, mid, and warm regions, respectively ( $\mathrm{F}=40.1$, $\mathrm{p}<0.001$; Fig 8b). Normalized to $\mathrm{C}$ loss, litter $\delta^{13} \mathrm{C}$ increased by $0.012 \pm 0.006 \%$ per \%C lost in the mid and warm regions, whereas the $\delta^{13} \mathrm{C}$ values of litter in the cold sites showed no 
significant change $(0.002 \pm 0.004 \%$ o per $\% \mathrm{C}$ lost; $\mathrm{F}=47.5, \mathrm{p}<0.001)$.

\subsection{Evidence for differences in $\delta^{13} \mathrm{C}$ of microbial biomass inputs and/or CUE along the transect}

We detected a significant positive correlation between $\varepsilon_{b i o m-b u l k}$ and $\varepsilon_{r L}$ (Fig 9a) with a regression slope 0.78 (95\% CI: 0.23-1.36). Similar trends were found for five out of ten individual PLFA, although statistical significance was reached only with two individual PLFA (16:0 and 16:1 07 ; Supporting information S9). Mass balance models indicated the observed data can be explained in two ways (Table 3 ), that is, (1) by a difference in microbial $\mathrm{C}$ allocation among transect regions that altered the extent to which ${ }^{13} \mathrm{C}$ was enriched in biomass relative to substrates $\left(\Delta \varepsilon_{\text {biom-subs }}=0.51-2.02 \%\right.$; higher in the mid and warm compared to the cold region $)$; and (2) by the combination of different substrate use $\left(\Delta \varepsilon_{\text {subs-bulk }}=0.50-1.74 \%\right.$; higher in the warmer regions $)$ and necromass production per unit of $\mathrm{C}$ consumed by microorganisms $\left(\triangle C U E_{C}=0.04-0.35\right.$; higher in the warmer regions). In contrast, a difference in microbial substrate use ( $\varepsilon_{\text {subs-bulk }}$ ), by itself (with constant $C U E_{C}$ and $\varepsilon_{b i o m-s u b s}$ values), could not explain the observed data. Both mechanisms could also have co-occurred, resulting in changes in all three parameters. Possible solutions consistent with the observed data are shown in Supporting Information S5.

\section{Discussion}

4.1. A warmer and wetter climate can shift the structure and function of the microbial community, altering the products of litter decay available for incorporation into the soil profile.

Our observations of the microbial community structure and function at the litter layer, the litter decomposition process and the chemical nature of litter inputs to SOM across this forest transect (Fig. 10) indicates two important climate effects on soil processes in mesic boreal forests:

(1) A warmer and wetter climate can enhance bacterial over fungal membership of the microbial community and thus shift microbial metabolisms in ways important to SOM formation. Our finding that composition and $\delta^{13} \mathrm{C}$ values of PLFA in the litter layer differ along the transect supports our first hypothesis that climate change can lead to changes in composition and activity of the microbial community in decomposing litter. Most importantly, climate change, as simulated through observations across this climate transect, can lead to a substantial ( $43 \pm 28 \%$ [95\% CI] ) decrease in fungal relative to bacterial biomass, consistent with shifts observed from mid to southern taiga sites in a Siberian latitudinal transect (Schnecker et al., 2015). The negative correlation between $\mathrm{F}: \mathrm{B}$ and $\mathrm{C}: \mathrm{N}$ ratios (Fig 2a) suggests that this shift results from greater $\mathrm{N}$ availability, rather than direct temperature effects. This is in agreement with previous studies that showed a negative correlation between $\mathrm{C}: \mathrm{N}$ and $\mathrm{F}: \mathrm{B}$ ratios in boreal soils (Blaško et al., 2013). Several mechanisms for this relationship between $\mathrm{C}: \mathrm{N}$ and $\mathrm{F}: \mathrm{B}$ ratios have been suggested. Fungal biomass, for example, exhibits a wider range in $\mathrm{C}: \mathrm{N}$ ratio than bacterial biomass. Fungi, therefore, have a competitive advantage in low-N environments (Strickland \& Rousk, 2010) but may be at a disadvantage when $\mathrm{N}$ availability is increased. Mycorrhizal fungi, which play a key role in 
alleviating the $\mathrm{N}$ limitation of boreal trees, are particularly affected by increased $\mathrm{N}$ availability (Blaško et al., 2013).

The strong decrease in F:B ratio with a warmer and wetter climate along this transect might signify an important climate-driven mechanism impacting SOM formation because fungi are likely to convert a greater fraction of litter $\mathrm{C}$ into stabilized secondary microbial compounds than bacteria (Waring et al., 2013). For example, soil with higher proportions of fungi retain a greater fraction of ${ }^{13} \mathrm{C}$ labelled litter in experimental incubations (Malik et al., 2016). Climate warming might therefore decrease the production of slower-turnover microbial necromass on decomposition litter.

In addition, our data indicate that a warmer and wetter climate induces a change in microbial substrate use patterns and/or in the allocation of microbial $\mathrm{C}$ towards respired $\mathrm{CO}_{2}$ and distinct microbial metabolites. The $1 \%$ increase in the $\delta^{13} \mathrm{C}$ values of microbial biomass relative to the bulk litter layer, based upon the change in the $\delta^{13} C_{\text {PLFA }}$ relative to bulk $\delta^{13} C_{\text {bulk, implies a }}$ meaningful shift in microbial metabolisms given that variations in $\delta^{13} \mathrm{C}$ values of plant and microbial compounds are on the order of a few per mil. Lignin, for example, is typically ${ }^{13} \mathrm{C}$ depleted by 2-6\% relative to cellulose (Benner et al., 1987; Hobbie \& Werner, 2004), and aliphatic compounds (lipids and waxes) are typically depleted by $2-9 \%$ relative to bulk plant material (Hobbie \& Werner, 2004).

(2) A warmer and wetter climate will change the identity of litter decay products generated at the litter layer. Despite the similar $\mathrm{C}$ chemistry of initial needle litter from all transect regions, we found significant differences between litter samples retrieved from distinct transect regions after 11-12 months of decomposition, despite a similar degree of decomposition. This confirms our second hypothesis that litter is processed differently in the distinct transect regions and indicates that litter processing is prone to change under a warmer climate. More specifically, our results indicate that under a warmer and wetter climate, litter will retain a lower relative proportion of alkyl-C (lipids and waxes) and a greater relative proportion of O-alkyl-C (carbohydrates) during decomposition than under the current climate. This suggests that compounds available to enter the underlying mineral soils post-decay may receive OM exhibiting lower alkyl:O-alkyl ratios in a warmer climate (Fig. 9a), in contrast to trends observed with experimental warming of organic layers in a temperate forest (Feng et al., 2008). In that study, soil warming lead to increased concentrations of cuticular lipids and decreasing concentrations of lignin phenols. Combined, these observations support the contrasting role of indirect climate effects like increased $\mathrm{N}$ availability, rather than direct temperature effects, on soil compositional changes with decomposition in these mesic forests.

Our observations that litter $\delta^{13} \mathrm{C}$ values increase faster during decomposition under a warmer climate are consistent with enhanced discrimination of extracellular enzymes against ${ }^{13} \mathrm{C}$ with rising temperatures (Lehmeier et al., 2016), as well as differential decomposition effects on litter chemistry with climate change. Aliphatic compounds like lipids and plant waxes are ${ }^{13} \mathrm{C}$ depleted relative to other compounds, while carbohydrates are more enriched (Bruno Glaser \& Amelung, 2002). Greater decomposition of aliphatic compounds and greater relative retention of 
carbohydrates under a warmer climate would, therefore, lead to an accelerated enrichment of ${ }^{13} \mathrm{C}$ during decomposition (Preston et al., 2009). This differential processing of litter in response to environmental conditions has been observed in laboratory and field experiments including those exploring land use practices on agricultural soils or $\mathrm{N}$ fertilization (Baumann et al., 2009; Glassman et al., 2018; Wickings et al., 2011, 2012). However, to our knowledge this is the first study to demonstrate that such differential processing at the litter layer can result from indirect effects of warming such as enhanced $\mathrm{N}$ availability.

\subsection{Microbial necromass shapes regional differences in decaying litter chemistry to a greater extent than selective removal of plant compounds.}

Our data provide two lines of support for our third hypothesis that regional differences in how litter chemistry changes during decomposition resulted primarily from distinct necromass inputs rather than the removal of a distinct litter fraction.

(1) The isotopic composition of microbial biomass co-varies with that of the remaining litter rather than the lost litter fraction.

We posited that ${ }^{13} \mathrm{C}$ isotopic fractionation prior to and after microbial substrate uptake represents substrate use patterns and microbial anabolism with its resulting necromass inputs, respectively, and that these two groups of processes can be distinguished by comparing the ${ }^{13} \mathrm{C}$ fractionation between initial and residual litter to ${ }^{13} \mathrm{C}$ fractionation between bulk litter and microbial biomass (Fig 1).

The positive correlation between $\varepsilon_{r L}$ and $\Delta^{13} C_{P L F A-S O C}$ observed in this study (Figure $9 \mathrm{~b}$ ) indicates that ${ }^{13} \mathrm{C}$ was more rapidly enriched in residual litter at sites where microbial biomass was also more ${ }^{13} \mathrm{C}$-enriched, even after accounting for differences in bulk litter $\delta^{13} \mathrm{C}$ values. Such a relationship cannot be explained by differences in substrate use patterns (Fig 1b) alone: In this case, sites where ${ }^{13} \mathrm{C}$-enriched substrates were preferentially decomposed would contain ${ }^{13} \mathrm{C}$ enriched microbial biomass but exhibit slower ${ }^{13} \mathrm{C}$ enrichment in the residual litter, which would have resulted in a negative correlation between $\varepsilon_{r L}$ and $\triangle^{13} C_{P L F A-S O C}$ across transect sites. Instead, our results suggest that the divergence in litter chemistry during decomposition under different environmental conditions observed by us and others (Baumann et al., 2009; Glassman et al., 2018; Morrison et al., 2019; Wang et al., 2019; Wickings et al., 2011, 2012) are driven by alterations of the microbial anabolism (Figs. 1c, 1d). While almost all microbial biomass $\mathrm{C}$ ultimately originates from litter $\mathrm{C}$, microbial metabolisms can affect $\mathrm{C}$ isotope fractionation during biomass biosynthesis through differences in the partitioning of $\mathrm{C}$ to respiration and biomass production, $\mathrm{C}$ allocation towards distinct compound classes, or both processes (Hayes, 2001).

It is likely that the observed changes in litter chemistry resulted from changes in the composition of necromass and other secondary microbial compounds added to litter (Fig. 1c). This inference is derived from mass balance calculations (Supporting Information S4, S5), which could be interpreted in two ways. First, a change in microbial necromass composition resulted in 
necromass being $0.51-2.02 \%$ more ${ }^{13} \mathrm{C}$-enriched relative to substrates in the warmer transect regions. This change falls within those differences in $\varepsilon_{\text {biom-subs }}\left(\right.$ i.e., $\delta^{13} \mathrm{C}_{\text {biomass }}-\delta^{13} \mathrm{C}_{\text {substrate }}$ ) observed in incubations of different species, substrates, or temperature (Abraham et al., 1998; Abraham \& Hesse, 2003; Lehmeier et al., 2016). This result could be explained if necromass in the warmer region contained less aliphatic $\mathrm{C}$ (lipids and waxes) and more carbohydrates and amino sugars, consistent with the greater accumulation of aliphatic $\mathrm{C}$ in cold region litter observed by NMR spectroscopy. Second, the observed stable $\mathrm{C}$ isotope values could also be explained by a combination of microorganisms consuming a more ${ }^{13} \mathrm{C}$-enriched $\mathrm{C}$ (i.e., more carbohydrates and less lipids) in the warmer region, and a larger fraction of this $\mathrm{C}$ retained on litter as necromass. However, such an interpretation is inconsistent with the chemical changes in decomposition litter observed by NMR spectroscopy, which followed the opposite trend: greater accumulation of ${ }^{13} \mathrm{C}$ depleted aliphatic $\mathrm{C}$ in colder transect regions. We thus conclude that necromass accumulation in the decaying litter is a key driver of litter chemistry (Fig. 1c).

To our best knowledge, this is the first study that attempts to identify whether environmental impacts on residual litter chemistry result from changes in the selective plant compound use or microbial necromass contributions. There are some limitations of our experimental approach: First, it is possible that decomposition in litterbags differed from the natural in situ litter decomposition in the litter layer, which would compromise the mass balance calculations. Second, it is possible that the difference in $\triangle^{13} C_{P L F A^{-} \text {bulk }}$ resulted from $\delta^{13} C_{P L F A^{-}}$ $\delta^{13} C_{\text {biomass }}$ rather than a difference in $\varepsilon$ biom-bulk, which would also violate the assumptions of our mass balance calculations. We did, however, previously review available $\delta^{13} \mathrm{C}_{\mathrm{PLFA}}-\delta^{13} \mathrm{C}_{\mathrm{biomass}}$ values and found no consistent difference between fungi and bacteria (Kohl et al., 2015). Furthermore, the $\delta^{13} \mathrm{C}$ values of individual PLFA exhibited the same patterns in all transect regions $(\mathrm{R}=0.975 \mathrm{p}<0.001$; Supporting Information $\mathrm{S} 10)$, and the differences in $\triangle^{13} C_{\text {PLFA-bulk among }}$ transect regions were observed in PLFA associated with all major individual groups (Fig. 5). Furthermore, a shift in $\delta^{13} \mathrm{C}_{\mathrm{PLFA}}-\delta^{13} \mathrm{C}_{\text {biomass }}$ would, by itself, be evidence of a change in the anabolic metabolism of litter decomposing microorganisms (Hayes, 2001). Another possibility is that litter in colder regions received greater carbon inputs with the ingrowth of fungal mycelia, which is assumed negligible in our isotope mass balance. This would be consistent with the absence of an increase of ${ }^{13} \mathrm{C}$ in the residual litter in cold region, as fungal biomass is likely ${ }^{13} \mathrm{C}$-depleted relative to bulk litter and bacterial biomass (Kohl et al., 2015). Again, this violation of our assumption would by itself be evidence for our main conclusions, i.e., differential inputs of litter necromass in the different climate regions. Finally, we cannot exclude that litter at warmer sites experienced greater $\mathrm{C}$ losses from litter due to enhanced leaching at warmer sites where litter was exposed to higher amounts of precipitation (Table 1). While litter $\mathrm{C}$ that is first taken up by microorganisms and then leached after excretion or cell lysis is included in our mass balance, direct leaching of litter $\mathrm{C}$ without prior uptake by microorganisms is assumed negligible. This is likely true given that leachate fluxes at all transect sites were at least 20-fold smaller than soil respiration (Ziegler et al., 2017). Regardless, leaching as a significant process remains inconsistent with the trends in litter composition as the greater retention of hydrophilic compounds (e.g. carbohydrates) and lesser 
accumulation of hydrophobic compounds (lipids and waxes) in warmer transect regions, i.e., the opposite trend of what would be observed due to greater leaching.

(2) The increase in alkyl-C relative to mass loss is unlikely to result from microbial substrate use alone. Our results show that the proportional accumulation of alkyl-C in litter from the cold region $(+30.6 \%)$ was comparable to the proportion of total C loss $(29.4 \%)$. It is unlikely that such a large relative increase in alkyl-C had occurred without the addition of aliphatic $\mathrm{C}$ from microbial necromass, as such a scenario would largely require that no alkyl- $\mathrm{C}$ had been degraded in these litterbags. This is not likely given that the alkyl-C fraction includes fatty acids in labile lipids (e.g., triglycerides and phospholipids) that are rapidly incorporated into microbial biomass (Miltner et al., 2009). In addition, raw NMR spectra (Supporting Information S5) show that the spectral regions in which we found the most divergent decomposition trends were different from the major peaks in the NMR spectra of initial plant material. These deviations were most common within the alkyl-C region of the spectra (at 20-25 and 38ppm), which as a whole exhibited the strongest divergence during decomposition. This suggests that compounds that were of minor importance in initial plant litter make up a substantial part of the additional alkyl-C in litter in the cold but not the warm region.

\subsection{The role of microbial necromass during litter decay on the compounds destined for the mineral soil profile must be considered to understand SOM in a changing climate.}

Our results demonstrate that the litter layer is a key location where direct (temperature) and indirect ( $\mathrm{N}$ availability, litter chemistry) climate impacts are translated into changes in organic matter chemistry. Across this boreal forest transect, this layer receives litter inputs with initially similar $\mathrm{C}$ chemistry but different $\mathrm{N}$ concentrations (Figs. 9b). During decomposition at sites with contrasting climate, litter $\mathrm{N}$ concentrations become more similar, while litter $\mathrm{C}$ chemistry (e.g. alkyl:O-alkyl ratios) become more distinct. Specifically, our results suggest that differential necromass inputs generated produced residual litter with lower alkyl:O-alkyl ratios in warmer transect regions.

Litter residuals from late decomposition stages are the principal precursor of organic matter in the forest floor and particulate organic matter (POM) in mineral horizons, two SOM pools whose persistence is primarily determined by its chemical recalcitrance and microbial inhibition to decomposition (Cotrufo et al., 2015). Lower alkyl-C:O-alkyl-C, as observed in litter residuals from warmer transect regions have been associated with faster turnover pools of soil organic matter (Baldock et al., 1992; Marty et al., 2019). The effects of a warmer climate on needle litter inputs may be interpreted as a potential mechanism increasing SOM bioreactivity (i.e., higher SOM decomposition rates under standardized conditions). If all other factors remain constant, this increase in bioreactivity could lead to a net loss of SOM from these forests. Relevant to climate change impacts on boreal forests, our previous work on these soils showed that SOM bioreactivity throughout the organic layer was shape by regional differences in litter input chemistry (Kohl et 
694

695

696

697

698

699

700

701

702

703

704

705

706

707

al., 2018). Climate effects imprinted upon organic matter at the litter-soil interface may thus shape SOM properties for decades to centuries.

\section{Conclusions}

In summary, we studied needle litter decomposition along a climate gradient where temperature and precipitation increased from cold to warm regions, resulting in similar soil moisture throughout the transect (Fig. 10). Across these sites a warmer climate history led to an accumulation of $\mathrm{N}$ in needle litter and soils, to changes in the microbial community composition (lower fungal:bacterial PLFA ratios) and physiology (evidenced by greater $\triangle^{13} C_{P L F A-b u l k}$ ). It is likely that these differences led to the differential changes to needle litter chemistry with decomposition observed in our litterbag experiment, i.e., greater retention of carbohydrates, lesser accumulation of lipids and waxes, and faster accumulation of ${ }^{13} \mathrm{C}$ in litter residual in the warmer region. This study highlights the role that microbial inputs during early litter decomposition can play in shaping residual needle litter contributions to soils as they respond to indirect climate warming effects such as greater nitrogen availability.

\section{Acknowledgements}

We thank Jerome Laganiere and Thalia Soucy Giguere for field sampling, Rachelle Dove and Julia Ferguson for help with laboratory work, and Geert Van Biesen, Alison Pye, and Celine Schneider for IRMS and NMR measurements. Andrea Skinner, Sara Thompson, Dave Meade, and Danny Pink assisted with litterfall collection and processing. We furthermore thank Penny L. Morrill and Kenneth Peltokangas for comments on an earlier draft the manuscript. This study was funded by the Natural Sciences and Engineering Research Council of Canada (SPG\#479224-15 and RGPIN\#341863), the Canadian Forest Service (Natural Resources Canada), the Center for Forestry Science and Innovation (Forestry and Agrifoods, Government of Newfoundland and Labrador), and the Canada Research Chairs program. LK holds a Marie Skłodowska-Curie Actions Individual Fellowship (\#4100210 PaTreME).

\section{Author contributions}

LK, KAE, SAB, and SEZ conceived of the study. KAE and SEZ maintained the field sites and KAE conducted the litterbag experiment. LK, FAP, KAE and JW conducted laboratory analyses. LK and AMP analysed the data. LK wrote the first draft of the manuscript with frequent inputs from SEZ. All other coauthors contributed to the text of the final manuscript.

\section{Data sharing and accessability}

The data that support the findings of this study are available from the corresponding author upon reasonable request. 


\section{$\underline{\text { References }}$}

Abraham, W., \& Hesse, C. (2003). Isotope fractionations in the biosynthesis of cell components by different fungi: a basis for environmental carbon flux studies. FEMS Microbiology Ecology, 46(1), 121-128. https://doi.org/10.1016/S0168-6496(03)00203-4

Abraham, W., Hesse, C., \& Pelz, O. (1998). Ratios of Carbon Isotopes in Microbial Lipids as an Indicator of Substrate Usage. Applied and Environmental Microbiology, 64(11), 4202-4209. https://doi.org/10.1128/AEM.64.11.4202-4209.1998.

Abrajano, T., Murphy, D., Fang, J., Comet, P., \& Brooks, J. (1994). 13C/12C ratios in individual fatty acids of maarine mytilids with and without bacterial symbionts. Organic Geochemistry, 21(6/7), 611-617. https://doi.org/10.1016/0146-6380(94)90007-8

Baldock, J., Oades, J., Waters, A., Peng, X., Vassallo, A., \& Wilson, M. (1992). Aspects of the Chemical Structure of Soil Organic Materials as Revealed by Solid-State 13 C NMR Spectroscopy. Biogeochemistry1, 16(1), 1-42. https://doi.org/10.1007/BF02402261

Barron, P. F., Wilson, M. A., Stephens, J. F., Cornell, B. A., \& Tate, K. R. (1980). Cross-polarization 13C NMR spectroscopy of whole soils. Nature, 286(5773), 585-587. https://doi.org/10.1038/286585a0

Baumann, K., Marschner, P., Smernik, R., \& Baldock, J. (2009). Residue chemistry and microbial community structure during decomposition of eucalypt, wheat and vetch residues. Soil Biology and Biochemistry, 41(9), 1966-1975. https://doi.org/10.1016/j.soilbio.2009.06.022

Benner, R., Fogel, M., Spargue, K., \& Hodson, R. (1987). Depletion of 13C in lignin and its implications for stable carbon isotope studies. Nature, 329(6141), 708-710. https://doi.org/doi:10.1038/329708a0

Berg, B, \& McClaugherty, C. (2008). Plant Litter. Decomposition, Humus Formation, Carbon Sequestration. Springer.

Berg, Björn, \& Meentemeyer, V. (2002). Litter quality in a north European transect versus carbon storage potential. Plant and Soil, 242(1), 83-92. https://doi.org/10.1023/A:1019637807021

Biasi, C., Rusalimova, O., Meyer, H., Kaiser, C., Wanek, W., Barsukov, P., Junger, H., \& Richter, A. (2005). Temperature-dependent shift from labile to recalcitrant carbon sources of arctic heterotrophs. Rapid Communications in Mass Spectrometry, 19(11), 1401-1408. https://doi.org/10.1002/rcm.1911

Blair, N., Leu, A., Muñoz, E., Olsen, J., Kwong, E., \& Des Marais, D. (1985). Carbon isotopic fractionation in heterotrophic microbial metabolism. Applied and Environmental Microbiology, 50(4), 996-1001.

Blaško, R., Högberg, P., Bach, L. H., \& Högberg, M. N. (2013). Relations among soil microbial community composition, nitrogen turnover, and tree growth in N-loaded and previously N-loaded boreal spruce forest. Forest Ecology and Management, 302, 319-328. https://doi.org/10.1016/J.FORECO.2013.02.035

Chao, L., Liu, Y., Freschet, G. T., Zhang, W., Yu, X., Zheng, W., Guan, X., Yang, Q., Chen, L., Dijkstra, F. A., \& Wang, S. (2019). Litter carbon and nutrient chemistry control the magnitude of soil priming effect. Functional Ecology, 33(5), 876-888. https://doi.org/10.1111/1365-2435.13278

Churchland, C., Grayston, S., \& Bengtson, P. (2013). Spatial variability of soil fungal and bacterial abundance: Consequences for carbon turnover along a transition from a forested to clear-cut site. Soil Biology and Biochemistry, 63, 5-13. https://doi.org/10.1016/j.soilbio.2013.03.015 
Cifuentes, L., \& Salata, G. (2001). Signicance of carbon isotope discrimination between bulk carbon and extracted phospholipid fatty acids in selected terrestrial and marine environments. Organic Geochemistry, 32, 613-621. https://doi.org/doi:10.1016/S0146-6380(00)00198-4

Clemmensen, K. E., Bahr, A., Ovaskainen, O., Dahlberg, A., Ekblad, A., Wallander, H., Stenlid, J., Finlay, R. D., Wardle, D. A., \& Lindahl, B. D. (2013). Roots and Associated Fungi Drive LongTerm Carbon Sequestration in Boreal Forest. Science, 339(March), 1615-1618. https://doi.org/10.1126/science.1231923

Coffin, R., Velinsky, D., Devereux, R., Prince, W., \& Cifuentes, L. (1990). Stable carbon isotope analysis of nucleic acids to trace sources of dissolved substrates used by estuarine bacteria. Applied and Environmental Microbiology, 56(7), 2012-2020. https://doi.org/10.1128/aem.56.7.2012-2020.1990

Conant, R., Ryan, M., Ågren, G., Birge, H., Davidson, E., Eliasson, P., Evans, S., Frey, S., Giardina, C., Hopkins, F., Hyvönen, R., Kirschbaum, M., Lavallee, J., Leifeld, J., Parton, W., Steinweg, M., Wallenstein, M., Wetterstedt, J., \& Bradford, M. (2011). Temperature and soil organic matter decomposition rates - synthesis of current knowledge and a way forward. Global Change Biology, 17, 3391-3404. https://doi.org/10.1111/j.1365-2486.2011.02496.x

Cooke, M. P., Talbot, H. M., \& Farrimond, P. (2008). Bacterial populations recorded in bacteriohopanepolyol distributions in soils from Northern England. Organic Geochemistry, 39(9), 1347-1358. https://doi.org/10.1016/j.orggeochem.2008.05.003

Cooke, M., Talbot, H., \& Wagner, T. (2008). Tracking soil organic carbon transport to continental margin sediments using soil-specific hopanoid biomarkers: A case study from the Congo fan (ODP site 1075). Organic Geochemistry, 39(8), 965-971. https://doi.org/10.1016/j.orggeochem.2008.03.009

Cotrufo, M. F., Soong, J. L., Horton, A. J., Campbell, E. E., Haddix, M. L., Wall, D. H., \& Parton, W. J. (2015). Formation of soil organic matter via biochemical and physical pathways of litter mass loss. Nature Geoscience, 8(10), 776-779. https://doi.org/10.1038/ngeo2520

Cotrufo, M., Wallenstein, M., Boot, C., Denef, K., \& Paul, E. (2013). The Microbial Efficiency-Matrix Stabilization (MEMS) framework integrates plant litter decomposition with soil organic matter stabilization: do labile plant inputs form stable soil organic matter? Global Change Biology, 19, 988-955. https://doi.org/10.1111/gcb.12113

Coûteaux, M.-M., Bottner, P., \& Berg, B. (1995). Litter decomposition, climate and liter quality. Trends in Ecology and Evolution, 10(2), 63-66. https://doi.org/10.1016/S0169-5347(00)88978-8

Craine, J., Morrow, C., \& Fierer, N. (2007). Microbial nitrogen limitation increases decomposition. Ecology, 88(8), 2105-2113. https://doi.org/10.1890/06-1847.1

Cusack, D. F., Silver, W. L., Torn, M. S., Burton, S. D., \& Firestone, M. K. (2011). Changes in microbial community characteristics and soil organic matter with nitrogen additions in two tropical forests. Ecology, 92(3), 621-632. https://doi.org/10.1890/10-0459.1

Environment Canada. (2014). Canadian Climate Normals or Averages 1981-2010.

Feng, X., Simpson, A., Wilson, K., Williams, D., \& Simpson, M. (2008). Increased cuticular carbon sequestration and lignin oxidation in response to soil warming. Nature Geoscience, 1(12), 836-839. https://doi.org/10.1038/ngeo361

Fogel, M. L., \& Cifuentes, L. A. (1993). Isotope fractionation during primary production. Organic Geochemistry: Principles and Applications, August, 73-98. https://doi.org/10.1007/978-1-46152890-6_3 
Frostegård, Å., Tunlid, A., \& Baarth, E. (1993). Communities from Two Soil Types Metals Phospholipid Fatty Acid Composition, Biomass, and Activity of Microbial Communities from Two Soil Types Experimentally Exposed to Different Heavy Metals. Applied and Environmental Microbiology, 59(11), 3605-3616.

Frostegård, Å., Tunlid, A., \& Bååth, E. (2010). Use and misuse of PLFA measurements in soils. Soil Biology and Biochemistry, 43(8), 1621-1625. https://doi.org/10.1016/j.soilbio.2010.11.021

Glaser, B. (2005). Compound-specific stable-isotope ( $813 \mathrm{C})$ analysis in soil science. Journal of Plant Nutrition and Soil Science, 168(5), 633-648. https://doi.org/10.1002/jpln.200521794

Glaser, Bruno, \& Amelung, W. (2002). Determination of 13C natural abundance of amino acid enantiomers in soil: Methodological considerations and first results. Rapid Communications in Mass Spectrometry, 16, 891-898. https://doi.org/10.1002/rcm.650

Glassman, S. I., Weihe, C., Li, J., Albright, M. B. N., Looby, C. I., Martiny, A. C., Treseder, K. K., Allison, S. D., \& Martiny, J. B. H. (2018). Decomposition responses to climate depend on microbial community composition. Proceedings of the National Academy of Sciences of the United States of America, 115(47), 11994-11999. https://doi.org/10.1073/pnas.1811269115

Grandy, S., \& Neff, J. (2008). Molecular C dynamics downstream: the biochemical decomposition sequence and its impact on soil organic matter structure and function. The Science of the Total Environment, 404(2-3), 297-307. https://doi.org/10.1016/j.scitotenv.2007.11.013

Grogan, D. W., \& Cronan, J. E. (1997). Cyclopropane ring formation in membrane lipids of bacteria. Microbiology and Molecular Biology Reviews, 61(4), 429-441.

Grosso, F., Bååth, E., \& De Nicola, F. (2016). Bacterial and fungal growth on different plant litter in Mediterranean soils: Effects of C/N ratio and soil pH. Applied Soil Ecology, 108, 1-7. https://doi.org/10.1016/J.APSOIL.2016.07.020

Hayes, J. (2001). Fractionation of Carbon and Hydrogen Isotopes in Biosynthetic Processes. Reviews in Mineralogy and Geochemistry, 43(March), 225-277. https://doi.org/10.2138/gsrmg.43.1.225

Hobbie, E., \& Werner, R. (2004). Intramolecular, compound-specific, and bulk carbon isotope patterns in C3 and C4 plants: a review and synthesis. New Phytologist, 161, 371-385. https://doi.org/10.1046/j.1469-8137.2004.00970.x

Högberg, M. N., Högberg, P., \& Myrold, D. D. (2007). Is microbial community composition in boreal forest soils determined by $\mathrm{pH}, \mathrm{C}$-to-N ratio, the trees, or all three? Oecologia, 150(4), 590-601. https://doi.org/10.1007/s00442-006-0562-5

Keiblinger, K. M., Hall, E. K., Wanek, W., Szukics, U., Hämmerle, I., Ellersdorfer, G., Böck, S., Strauss, J., Sterflinger, K., Richter, A., \& Zechmeister-Boltenstern, S. (2010). The effect of resource quantity and resource stoichiometry on microbial carbon-use-efficiency. FEMS Microbiology Ecology, 73(3), 430-440. https://doi.org/10.1111/j.1574-6941.2010.00912.x

Kindler, R., Miltner, A., Richnow, H., \& Kastner, M. (2006). Fate of gram-negative bacterial biomass in soil-mineralization and contribution to SOM. Soil Biology and Biochemistry, 38(9), 2860-2870. https://doi.org/10.1016/j.soilbio.2006.04.047

Kögel-Knabner, I. (2002). The macromolecular organic composition of Plant and microbial residues as inputs to soil organic matter. Soil Biology and Biochemistry, 34(2), 139-162. https://doi.org/10.1016/S0038-0717(01)00158-4

Kögel-Knabner, I., de Leeuw, J. W., \& Hatcher, P. G. (1992). Nature and distribution of alkyl carbon in 
forest soil profiles: implications for the origin and humification of aliphatic biomacromolecules. Science of the Total Environment, The, 117-118(C), 175-185. https://doi.org/10.1016/00489697(92)90085-7

Kögel, I., Hempfling, R., Zech, W., Hatcher, P. G., \& Schulten, H. R. (1988). Chemical composition of the organic matter in forest soils: 1. Forest litter. Soil Science, 146(2), 124-136. https://doi.org/10.1097/00010694-198808000-00011

Kohl, L., Laganière, J., Edwards, K. A., Billings, S. S. A., Morrill, P., Van Biesen, G., \& Ziegler, S. (2015). Distinct fungal and bacterial $\delta 13 \mathrm{C}$ signatures as potential drivers of increasing $\delta 13 \mathrm{C}$ of soil organic matter with depth. Biogeochemistry, 124(1-3), 13-26. https://doi.org/10.1007/s10533-015$0107-2$

Kohl, L., Philben, M., Edwards, K. A., Podrebarac, F. A., Warren, J., \& Ziegler, S. E. (2018). The origin of soil organic matter controls its composition and bioreactivity across a mesic boreal forest latitudinal gradient. Global Change Biology, 24(2), e458-e473. https://doi.org/10.1111/gcb.13887

Kuzyakov, Y., Friedel, J., \& Stahr, K. (2000). Review of mechanisms and quantification of priming effects. Soil Biology and Biochemistry, 32, 1485-1498. https://doi.org/10.1016/S00380717(00)00084-5

Laganière, J., Podrebarac, F., Billings, S., Edwards, K., \& Ziegler, S. (2015). A warmer climate reduces the bioreactivity of isolated boreal forest soil horizons without increasing the temperature sensitivity of respiratory CO2 loss. Soil Biology and Biochemistry, 84(November), 177-188. https://doi.org/10.1016/j.soilbio.2015.02.025

Lehmeier, C. A., Ballantyne IV, F., Min, K., \& Billings, S. A. (2016). Temperature-mediated changes in microbial carbon use efficiency and $13 \mathrm{C}$ discrimination. Biogeosciences, 13, 3319-3329. https://doi.org/10.5194/bg-13-3319-2016

Li, J., Ziegler, S., Lane, C., \& Billings, S. (2012). Warming-enhanced preferential microbial mineralization of humified boreal forest soil organic matter: Interpretation of soil profiles along a climate transect using laboratory incubations. Journal of Geophysical Research, 117(G2), 1-13. https://doi.org/10.1029/2011JG001769

Liu, M., Qiao, N., Xu, X., Fang, H., Wang, H., \& Kuzyakov, Y. (2020). C:N stoichiometry of stable and labile organic compounds determine priming patterns. Geoderma, 362. https://doi.org/10.1016/j.geoderma.2019.114122

Löhnis, F. (1926). Nitrogen availability of green manures. Soil Science, 22(4), 253-290.

Malik, A. A., Chowdhury, S., Schlager, V., Oliver, A., Puissant, J., Vazquez, P. G. M., Jehmlich, N., von Bergen, M., Griffiths, R. I., \& Gleixner, G. (2016). Soil Fungal:Bacterial Ratios Are Linked to Altered Carbon Cycling. Frontiers in Microbiology, 7, 1247. https://doi.org/10.3389/fmicb.2016.01247

Marty, C., Piquette, J., Morin, H., Bussières, D., Thiffault, N., Houle, D., Bradley, R. L., Simpson, M. J., Ouimet, R., \& Paré, M. C. (2019). Nine years of in situ soil warming and topography impact the temperature sensitivity and basal respiration rate of the forest floor in a Canadian boreal forest. PLOS ONE, 14(12), e0226909. https://doi.org/10.1371/journal.pone.0226909

Massiot, D., Fayon, F., Capron, M., King, I., Le Calvé, S., Alonso, B., Durand, J.-O., Bujoli, B., Gan, Z., \& Hoatson, G. (2002). Modelling one- and two-dimensional solid-state NMR spectra. Magnetic Resonance in Chemistry, 40(1), 70-76. https://doi.org/10.1002/mrc.984

Mathers, N., Jalota, R., Dalal, R., \& Boyd, S. (2007). 13C-NMR analysis of decomposing litter and fine 
roots in the semi-arid Mulga Lands of southern Queensland. Soil Biology and Biochemistry, 39(5), 993-1006. https://doi.org/10.1016/j.soilbio.2006.11.009

Matthews, E. (1997). Global litter production, pools, and turnover times: Estimates from measurement data and regression models. Journal of Geophysical Research, 102(D15), 18771-18800 zVZ. https://doi.org/10.1029/97JD02956

Melillo, J. M., Butler, S., Johnson, J., Mohan, J., Steudler, P., Lux, H., Burrows, E., Bowles, F., Smith, R., Scott, L., Vario, C., Hill, T., Burton, A., Zhou, Y.-M., \& Tang, J. (2011). Soil warming, carbonnitrogen interactions, and forest carbon budgets. Proceedings of the National Academy of Sciences of the United States of America, 108(23), 9508-9512. https://doi.org/10.1073/pnas.1018189108

Miltner, A., Kindler, R., Knicker, H., Richnow, H.-H., Kästner, M., \& Thullner, M. (2009). Fate of bacterial biomass derived fatty acids in soil and their contribution to soil organic matter. Organic Geochemistry, 40(9), 978-985. https://doi.org/10.1016/j.orggeochem.2009.06.008

Moore, T., Trofymow, J., Prescott, C., \& Titus, B. (2010). Nature and nurture in the dynamics of C, N and P during litter decomposition in Canadian forests. Plant and Soil, 339(1-2), 163-175. https://doi.org/10.1007/s11104-010-0563-3

Morrison, E. W., Pringle, A., van Diepen, L. T. A., Grandy, A. S., Melillo, J. M., \& Frey, S. D. (2019). Warming alters fungal communities and litter chemistry with implications for soil carbon stocks. Soil Biology and Biochemistry, 132, 120-130. https://doi.org/10.1016/j.soilbio.2019.02.005

Philben, M., Ziegler, S., Edwards, K., Kahler, R., \& Benner, R. (2016). Soil organic nitrogen cycling increase with temperature and precipitation along a boreal forest latitudinal transect. Biogeochemistry, 127(2-3), 397-410. https://doi.org/10.1007/s10533-016-0187-7

Prescott, C. (2010). Litter decomposition: what controls it and how can we alter it to sequester more carbon in forest soils? Biogeochemistry, 101(1-3), 133-149. https://doi.org/10.1007/s10533-0109439-0

Preston, C., Nault, J., \& Trofymow, J. (2009). Chemical Changes During 6 Years of Decomposition of 11 Litters in Some Canadian Forest Sites. Part 2. 13C Abundance, Solid-State 13C NMR Spectroscopy and the Meaning of "Lignin." Ecosystems, 12(7), 1078-1102. https://doi.org/10.1007/s10021-0099267-z

Preston, C., Trofymow, J., \& CIDET Working Group. (2000). Variability in litter quality and its relationship to litter decay in Canadian forests. Canadian Journal of Botany, 78, 1269-1287. https://doi.org/10.1139/cjb-78-10-1269

Price, D., Alfaro, R., Brown, K., Flannigan, M., Fleming, R., Hogg, E., Girardin, M., Lakusta, T., Johnston, M., Mckenney, D., Pedlar, J., Stratton, T., Sturrock, R., Thompson, I., Trofymow, J., \& Venier, L. (2013). Anticipating the consequences of climate change for Canada's boreal forest ecosystems [Article]. Environmental Reviews, 365(December), 322-365.

Qiao, N., Xu, X., Hu, Y., Blagodatskaya, E., Liu, Y., Schaefer, D., \& Kuzyakov, Y. (2016). Carbon and nitrogen additions induce distinct priming effects along an organic-matter decay continuum. Scientific Reports, 6(JANUARY), 19865. https://doi.org/10.1038/srep19865

Quideau, S., Chadwick, O., Benesi, A., Graham, R., \& Anderson, M. (2001). A direct link between forest vegetation type and soil organic matter composition. Geoderma, 104(1-2), 41-60. https://doi.org/10.1016/S0016-7061(01)00055-6

Quideau, S., Graham, R., Oh, S., Hendrix, P., \& Wasylishen, R. (2005). Leaf litter decomposition in a chaparral ecosystem, Southern California. Soil Biology and Biochemistry, 37(11), 1988-1998. 
R Development Core Team. (2015). R: A Language and Environment for Statistical Computing. R Foundation for Statistical Computing.

Ruess, L., \& Chamberlain, P. (2010). The fat that matters: Soil food web analysis using fatty acids and their carbon stable isotope signature. Soil Biology and Biochemistry, 42(11), 1898-1910. https://doi.org/10.1016/j.soilbio.2010.07.020

Schimel, J., \& Schaeffer, S. (2012). Microbial control over carbon cycling in soil. Frontiers in Microbiology, 3(September), 348. https://doi.org/10.3389/fmicb.2012.00348

Schnecker, J., Wild, B., Takriti, M., Eloy Alves, R., Gentsch, N., Gittel, A., Hofer, A., Klaus, K., Knoltsch, A., Lashchinskiy, N., Mikutta, R., \& Richter, A. (2015). Enzyme patterns in topsoil and subsoil horizons along a latitudinal transect in Western Siberia. Soil Biology and Biochemistry, 83, 106-115. https://doi.org/10.1016/j.soilbio.2015.01.016

Schneider, T., Gerrits, B., Gassmann, R., Schmid, E., Gessner, M. O., Richter, A., Battin, T., Eberl, L., \& Riedel, K. (2010). Proteome analysis of fungal and bacterial involvement in leaf litter decomposition. Proteomics, 10(9), 1819-1830. https://doi.org/10.1002/pmic.200900691

Schneider, T., Keiblinger, K. M., Schmid, E., Sterflinger-Gleixner, K., Ellersdorfer, G., Roschitzki, B., Richter, A., Eberl, L., Zechmeister-Boltenstern, S., \& Riedel, K. (2012). Who is who in litter decomposition? Metaproteomics reveals major microbial players and their biogeochemical functions. ISME Journal, 6(9), 1749-1762. https://doi.org/10.1038/ismej.2012.11

Schurig, C., Smittenberg, R., Berger, J., Kraft, F., Woche, S., Goebel, M.-O., Heipieper, H., Miltner, A., \& Kaestner, M. (2012). Microbial cell-envelope fragments and the formation of soil organic matter: a case study from a glacier forefield. Biogeochemistry, 113(1-3), 595-612. https://doi.org/10.1007/s10533-012-9791-3

Sterner, R. W., \& Elser, J. J. (2002). Ecological Stoichiometry. Princeton University Press.

Stewart, C. E., Moturi, P., Follett, R. F., \& Halvorson, A. D. (2015). Lignin biochemistry and soil N determine crop residue decomposition and soil priming. Biogeochemistry, 124(1), 335-351. https://doi.org/10.1007/s10533-015-0101-8

Strickland, M., \& Rousk, J. (2010). Considering fungal:bacterial dominance in soils - Methods, controls, and ecosystem implications. Soil Biology and Biochemistry, 42(9), 1385-1395. https://doi.org/10.1016/j.soilbio.2010.05.007

Trofymow, J., \& CIDET Working Group. (1998). The Canadian Intersite Decomposition Experiment Project and Site Establishment Report.

van Oldenborgh, G., Collins, M., Arblaster, J., Christensen, J., Marotzke, J., Power, S., Rummukainen, M., \& Zhou, T. (2013). Atlas of Global and Regional Climate Projections. In T. Stocker, D. Qin, G.K. Plattner, M. Tignor, S. Allen, J. Boschung, A. Nauels, Y. Xia, V. Bex, \& P. Midgley (Eds.), Climate Change 2013: The Physical Science Basis. Contribution of Working Group I to the Fifth Assessment Report of the Intergovernmental Panel on Climate Change (pp. 1311-1394). https://doi.org/10.1017/CBO9781107415324.029

VandenEnden, L., Frey, S. D., Nadelhoffer, K. J., LeMoine, J. M., Lajtha, K., \& Simpson, M. J. (2018). Molecular-level changes in soil organic matter composition after 10 years of litter, root and nitrogen manipulation in a temperate forest. Biogeochemistry, 141(2), 183-197. https://doi.org/10.1007/s10533-018-0512-4 
Wang, Y., Zheng, J., Boyd, S. E., Xu, Z., \& Zhou, Q. (2019). Effects of litter quality and quantity on chemical changes during eucalyptus litter decomposition in subtropical Australia. Plant and Soil, 442(1-2), 65-78. https://doi.org/10.1007/s11104-019-04162-2

Waring, B. G., Averill, C., \& Hawkes, C. V. (2013). Differences in fungal and bacterial physiology alter soil carbon and nitrogen cycling: Insights from meta-analysis and theoretical models. Ecology Letters, 16(7), 887-894. https://doi.org/10.1111/ele.12125

White, D., \& Ringelberg, D. (1998). Signature lipid biomarker analysis. In R. S. Burlage (Ed.), Techniques in Microbial Ecology (pp. 255-272). Oxford University Press.

Wickings, K., Grandy, S., Reed, S., \& Cleveland, C. (2011). Management intensity alters decomposition via biological pathways. Biogeochemistry, 104(1-3), 365-379. https://doi.org/10.1007/s10533-0109510-x

Wickings, K., Grandy, S., Reed, S., \& Cleveland, C. (2012). The origin of litter chemical complexity during decomposition. Ecology Letters, 15(10), 1180-1188. https://doi.org/10.1111/j.14610248.2012.01837.x

Wilson, M. (1987). N.M.R Techniques and Applications in Geochemistry and Soil Chemistry. Pergamon Press.

$\mathrm{Xu}, \mathrm{C} .$, \& Singh, V. (2001). Evaluation and generalization of temperature based methods for calculating evaporation. Hydrological Processes, 319, 305-319. https://doi.org/10.1002/(SICI)10991085(20000215)14:2<339::AID-HYP928>3.0.CO;2-O

Zech, W., Johansson, M.-B., Haumaier, L., \& Malcolm, R. L. (1987). CPMAS 13C NMR and IR spectra of spruce and pine litter and of the Klason lignin fraction at different stages of decomposition. Zeitschrift Für Pflanzenernährung Und Bodenkunde, 150(4), 262-265. https://doi.org/10.1002/jpln.19871500413

Ziegler, S., Benner, R., Billings, S., Edwards, K., Philben, M., Zhu, X., \& Laganiere, J. (2017). Climate change can accelerate carbon fluxes without changing soil carbon stocks. Frontiers in Earth Scienes, 5, 2. https://doi.org/10.3389/feart.2017.00002

Ziegler, S. E. S., White, P. M. P., Wolf, D. C. D., \& Thoma, G. J. G. (2005). Tracking the fate and recycling of 13C-labeled glucose in soil. Soil Science, 170(10), 767-778. https://doi.org/10.1097/00010694-200510000-00002 
(a) Decomposition model

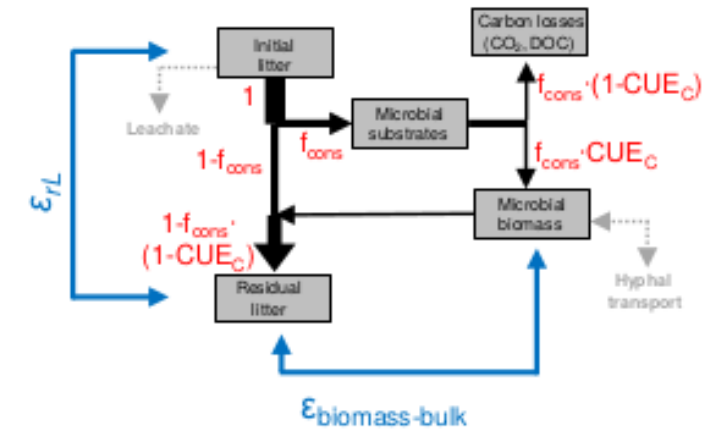

(c) Necromass composition determines residual chemistry

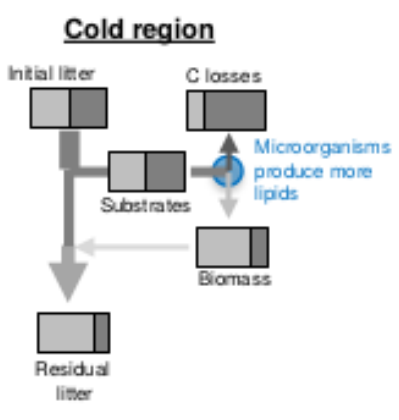

Warm region

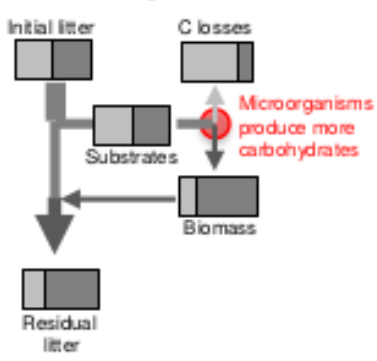

(b) Substrate use determines residual chemistry
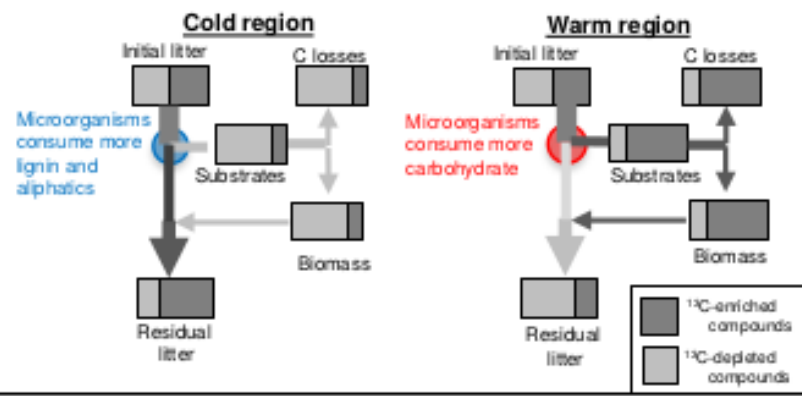

(d) Necromass amount determines residual chemistry Cold region

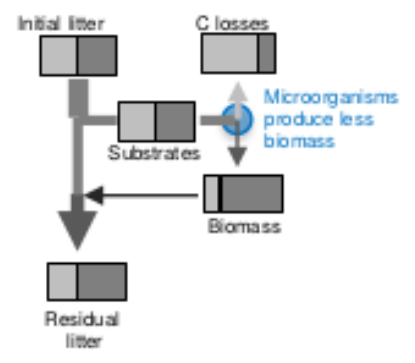

Warm region

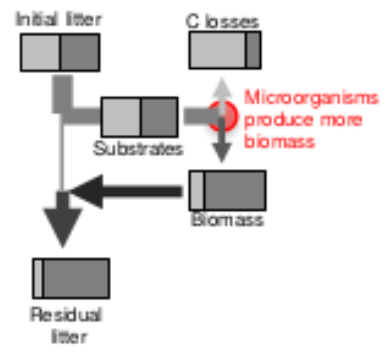

(e) Relationship between $\Delta^{13} C_{\text {PLFASOC }}$ and $\Delta^{13} C_{\text {residual - initial litter }}$

1001

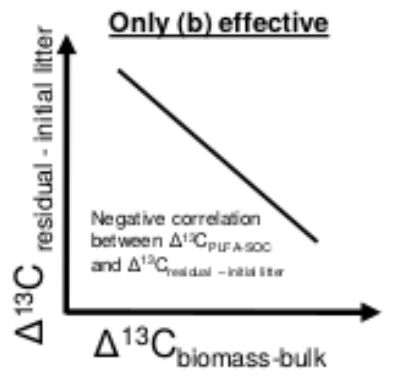

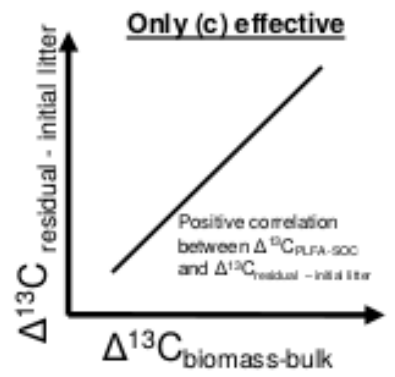
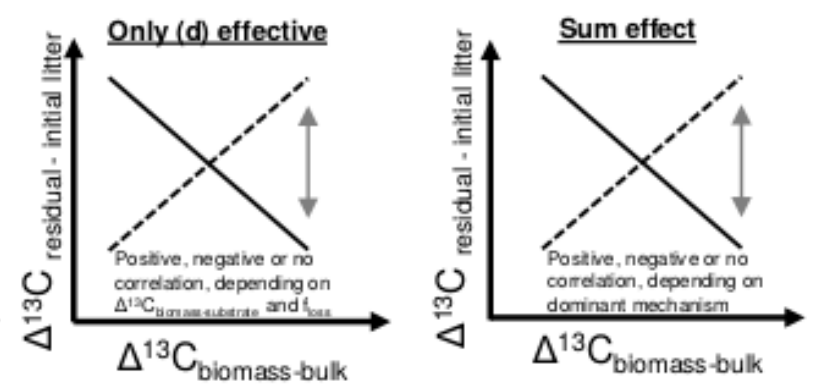

Figure 1. Conceptual figures depicting the conceptual model underyling our isotope mass balance calculations (a). Red numbers indicate carbon fluxes: $f_{\text {cons }}$, fraction of initial litter carbon taken up by soil microorganisms; $C U E_{C}$, community-level carbon use efficiency, defined as the fraction of carbon taken up by microorganisms that was converted into necromass (i.e., not respired as $\mathrm{CO}_{2}$ or leached). Dashed grey arrows indicate two fluxes we assume negligible: direct leaching of litter carbon without prior uptake by microorganisms, and $\mathrm{C}$ exchange between litter and deeper soil horizons due to fungal growths and hyphal transport. The blue formulae indicate the defined measures of stable isotope fractionation compared in this study: $\varepsilon_{\text {biom-bulk }}$ is the enrichment of ${ }^{13} \mathrm{C}$ in microbial biomass relative to bulk carbon (measured as $\delta^{13} \mathrm{C}_{\mathrm{PLFA}^{-}}$ $\delta^{13} \mathrm{C}_{\text {bulk }}$ ) and $\varepsilon_{r L}$ is enrichment of ${ }^{13} \mathrm{C}$ during decomposition. The term $\zeta=\frac{1-\mathrm{f}_{\text {lost }}}{\mathrm{f}_{\text {lost }}}$ normalizes $\varepsilon_{r L}$ to litter carbon loss $\left(\mathrm{f}_{\text {loss }}=\mathrm{f}_{\text {cons }} \cdot\left(1-\mathrm{CUE}_{\mathrm{C}}\right)\right)$. Furthermore, examples of how the stable isotope values would vary in different carbon pools if climate were to shape residual litter chemistry by changing substrate use patterns (b), microbial carbon allocation (c), or $C U E_{C}(\mathbf{d})$. Note that these panels are intended to illustrate relationships among the $\delta^{13} \mathrm{C}$ values as attributed to each of the three mechanisms, rather than to imply the 
1015 hypothesized direction of each effect along the climate transect. Moreover, the expected regression between $1016 \varepsilon_{\text {biom-bulk }}$ and $\varepsilon_{r L}(\mathbf{e})$ is provided to illustrate how results in this study are used to support our understanding 1017 of the role of these mechanisms and their response to climate. See Section 2.4 and Supporting Information 1018 S3-S4 for further discussion. 


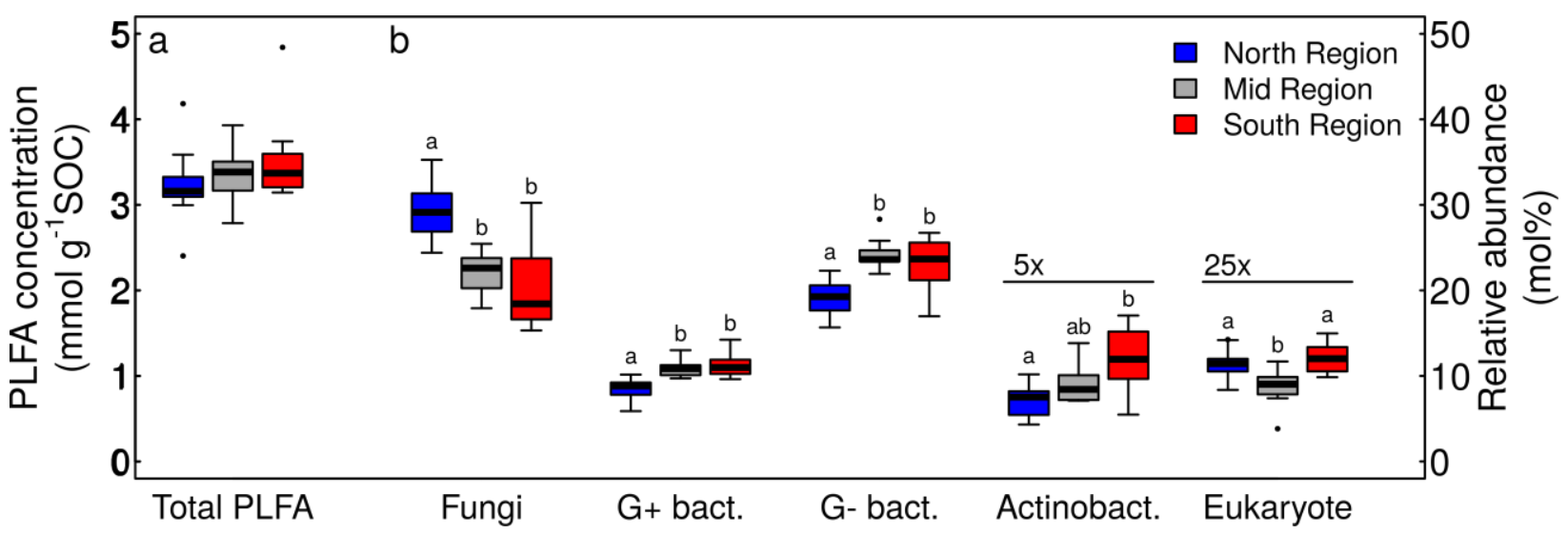

1021 Figure 2. Concentration of PLFA in the litter layer from three climate regions (a) and relative abundance of PLFA specific to broad microbial groups (b). Bold lines indicate the median, boxes the interquartile range, and whiskers the estimated $95 \%$ quantiles. Letters indicate significant differences among transect regions. The relative abundance of actinobacterial and eukaryotic PLFA was plotted at 5 and 25 times its true value respectively for better readability. 


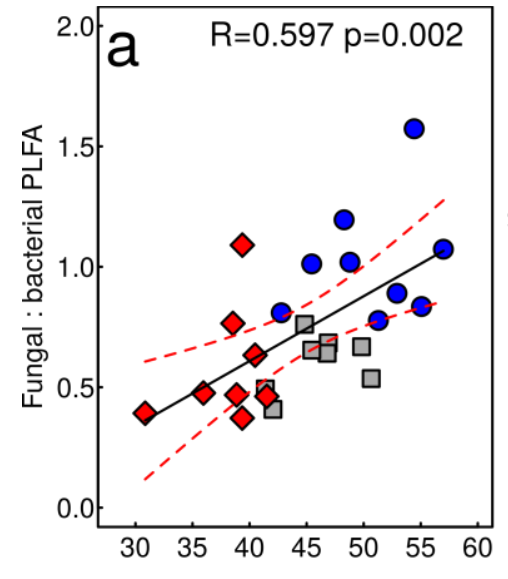

C:N ratio $(\mathrm{mol} / \mathrm{mol})$

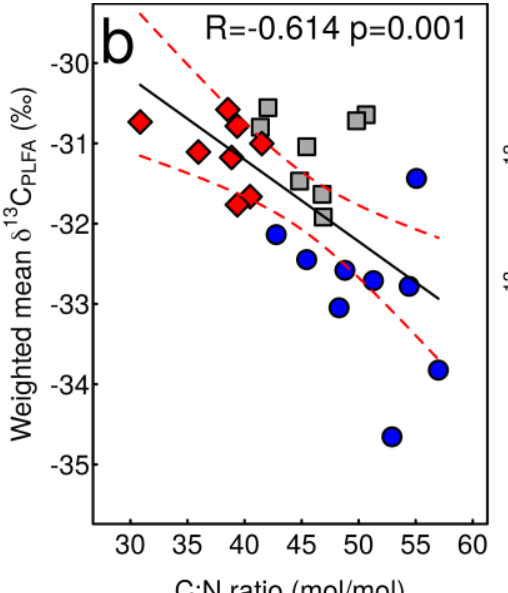

C:N ratio $(\mathrm{mol} / \mathrm{mol})$

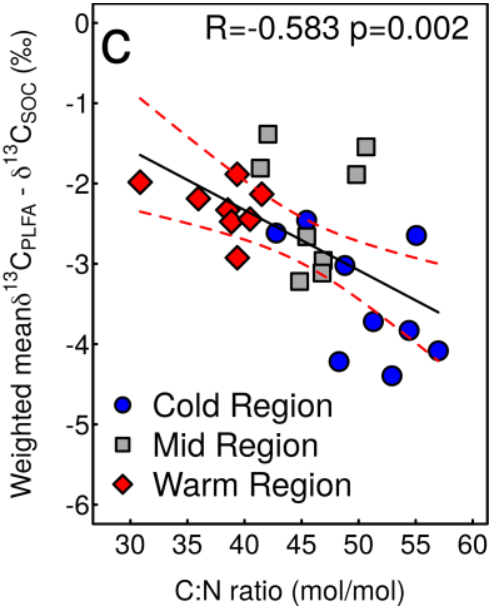

1027 Figure 3. Correlation between the $\mathrm{C}: \mathrm{N}$ ratio of the litter laeyr, fungal:bacterial PLFA ratio, and $\delta^{13} \mathrm{C}_{\mathrm{PLFA}}-\delta^{13} \mathrm{C}_{\text {bulk }}$ values. Colors and shapes indicate transect regions (blue, cold region; grey, mid region; red, warm region. Black lines indicate linear regressions, and dashed red lines indicate the $95 \%$ confidence interval for these regression lines. 

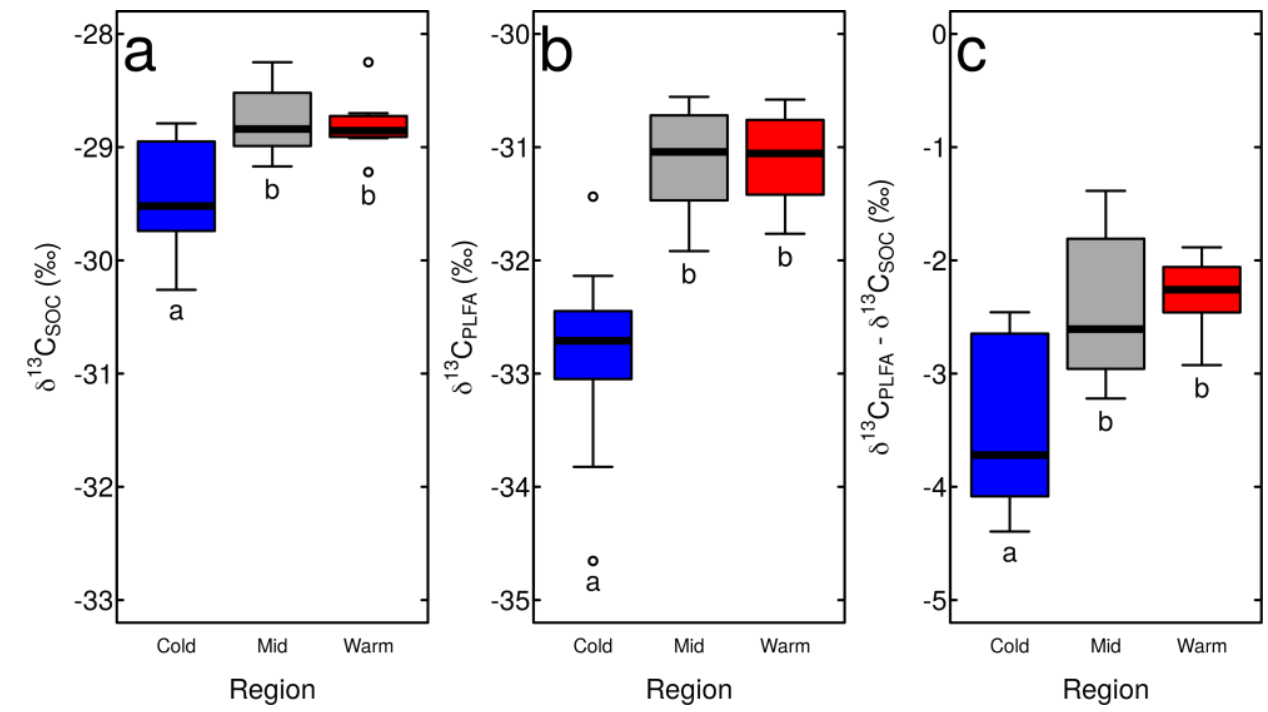

Figure 4. Bulk $\delta^{13} \mathrm{C}$ values of the litter layer (a), litter layer PLFA (b; weighted mean), and PLFA normalized to the bulk litter layer (c). Samples were collected in the three climate regions in a mesic boreal forest climate transect. Letters indicate significant differences between transect regions. Bold lines indicate the median of each region, boxes the interquartile range, and whiskers the $95 \%$ interval $(n=8-9)$. 


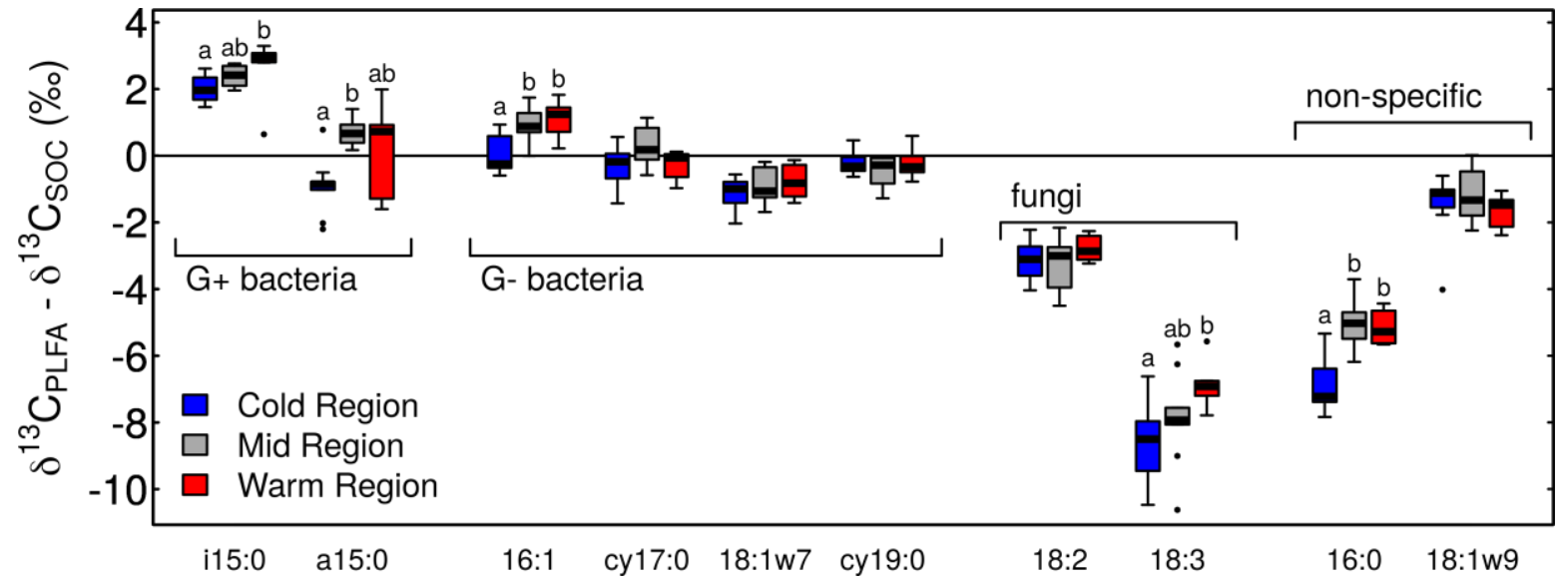

Figure 5. Stable $\mathrm{C}$ isotope values of phospholipid fatty acids realative to the bulk stable isotope value of the litter layer in three regions of a boreal forest latitudinal transect. Bold lines indicate the median, boxes the interquartile range, and whiskers the estimated 95\% range ( $\mathrm{n}=8-9$ ). Letters indicate significant differences among transect regions (Kruskal-Wallace test).

1040 

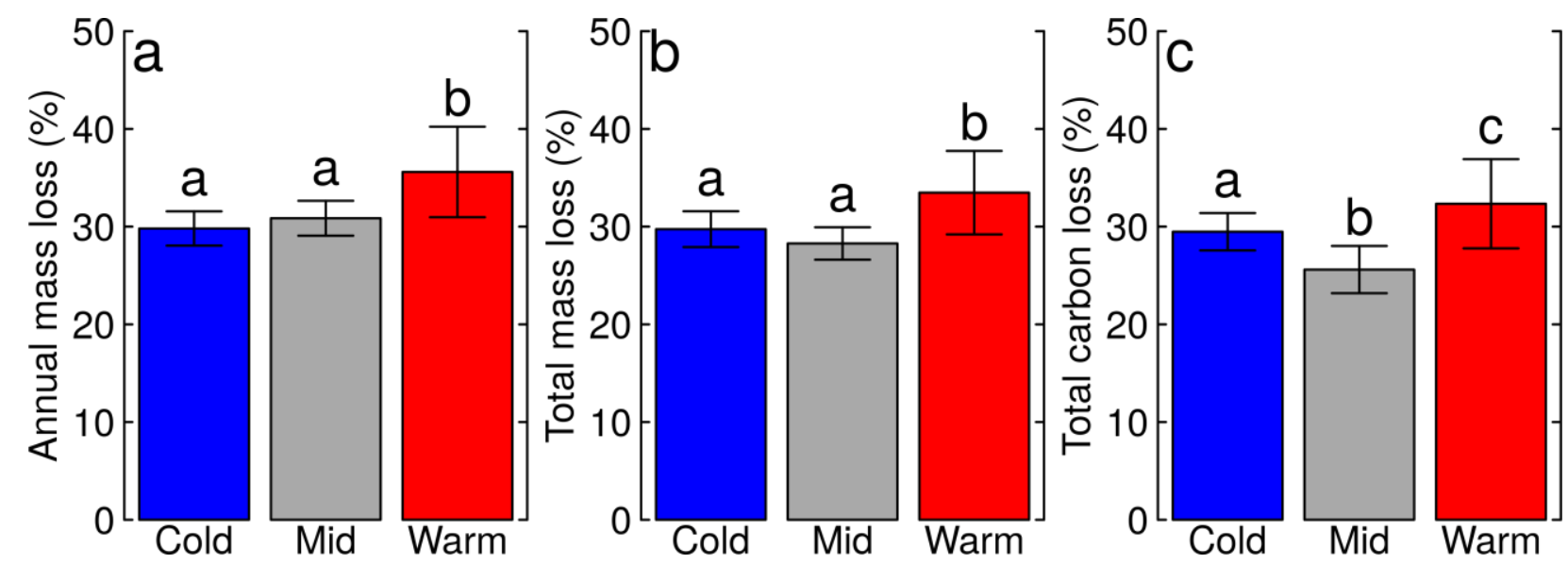

Figure 6. Mass and carbon loss of local litter in three regions of a boreal forest climate transect spanning from 0.0 to $5.2^{\circ} \mathrm{C}$. In each region, litterbags were filled with local balsam fir needles and retrieved after 11-12 months, aiming for similar total mass loss over the decomposition period. Mass loss is presented as expressed daily mass loss (a) and mass loss over the complete runtime of the experiment (b); carbon loss is presented as total carbon loss over the complete runtime of the experiment (c). Bars indicate the mean of 18 litterbags distributed among three distinct field sites per region, with error bars indicating one standard deviation. Letters indicate significant difference between transect regions. Note that the total mass loss depicted in (b) and (c) occurred over different decomposition times and should thus not be read as a comparison of decomposition rates. Rather, panels (b) and (c) serve to illustrate that the chemical and isotopic analyses were conducted when decomposition had reached a similar point at all transect sites. 


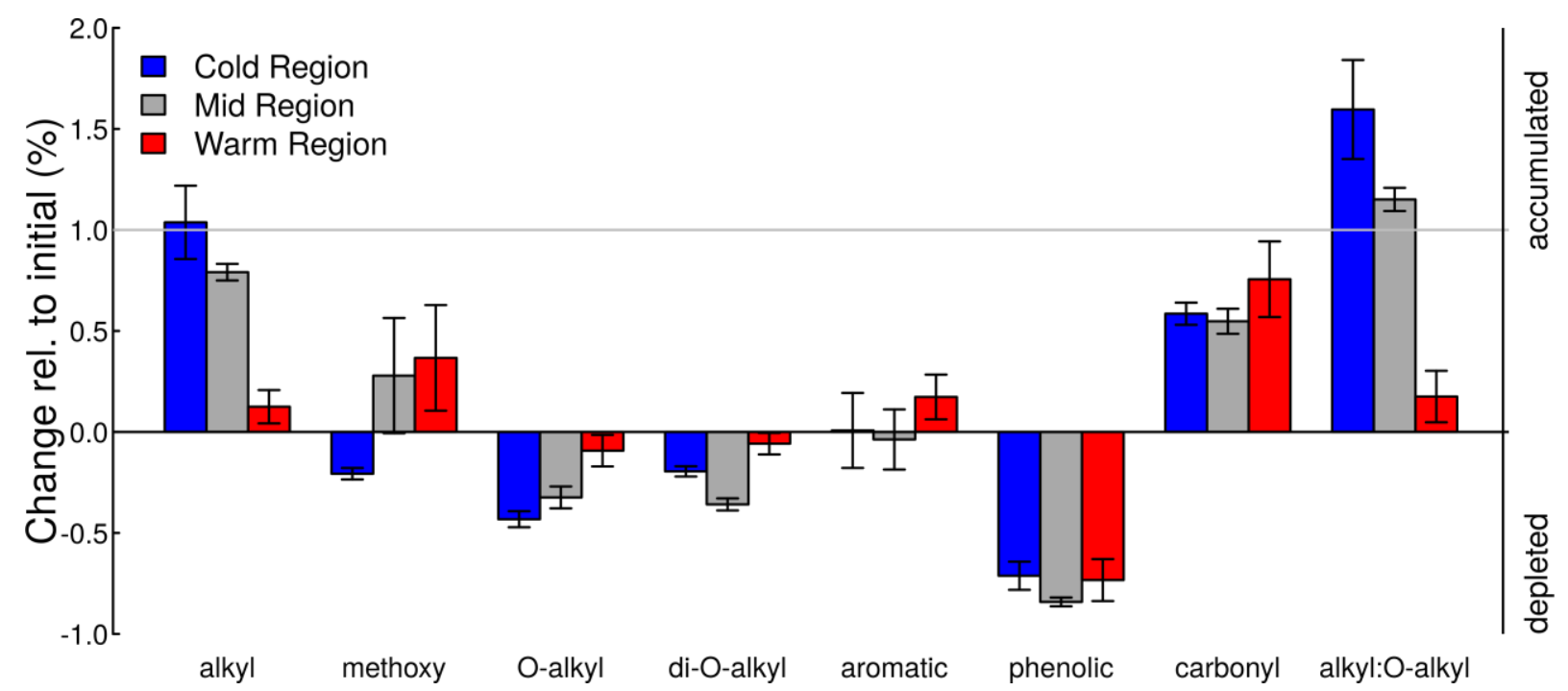

1052 Figure 7. Changes in litter chemistry during decomposition by region, expressed as the \% changes in the abundance of a functional group relative to its initial abundance (see eq. 3). Values larger than zero indicate that the abundance of a functional group increased during decomposition (i.e., net accumulation) while values smaller than zero indicate that the concentration decreased (i.e., net depletion). Note that changes in functional group abundance are the net result of both catabolic (preferential decomposition of some litter components relative to other components) and anabolic (inputs of secondary microbial compounds) metabolisms. Bars indicate the mean of litterbags decomposed at three replicate sites per region, with an error bar indicating one standard deviation. Letters indicate significant difference between transect regions. 

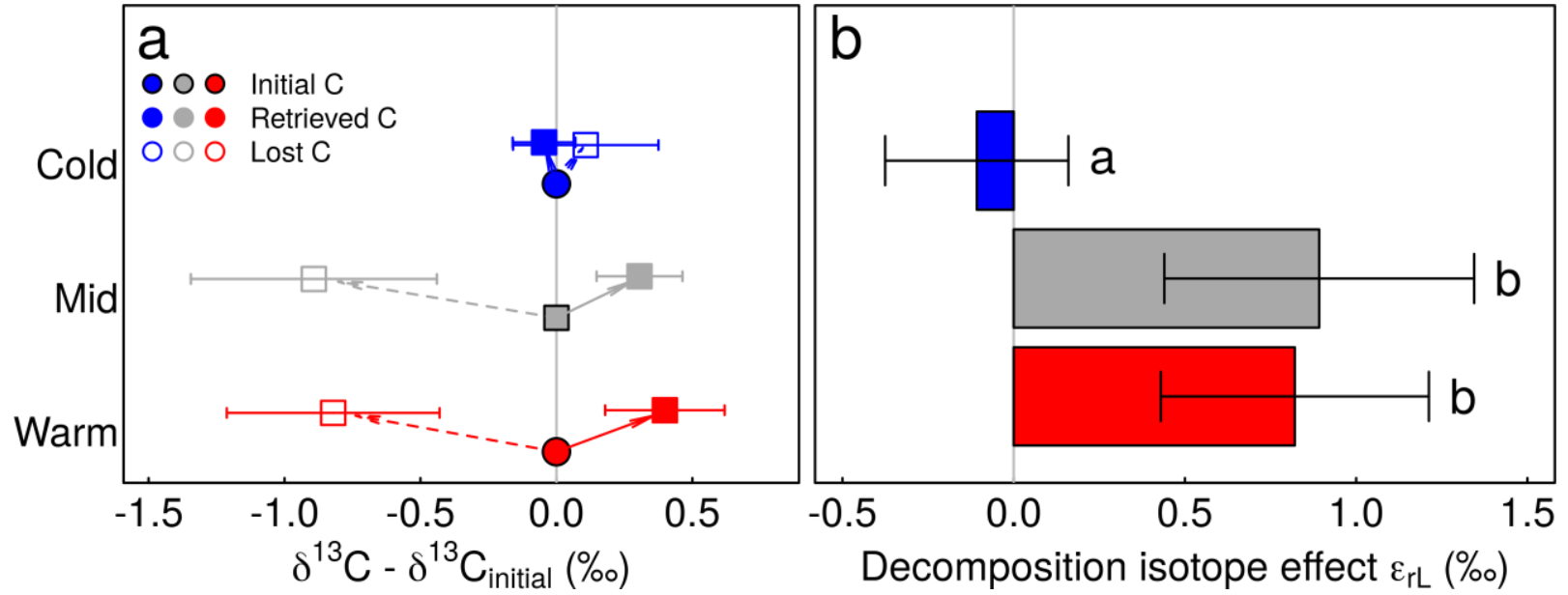

1060 Figure 8. Changes in $\delta^{13} \mathrm{C}$ values during litter decomposition in a litter bag experiment replicated in three transect regions of a climate transect spanning 5.0 C MAT. The two panels depict the $\delta^{13} \mathrm{C}$ values of retrieved litter and the lost litter fraction normalized to initial litter (a) and isotope enrichment effect associated with litter decomposition $(\varepsilon r L ; \mathbf{b})$. Points and bars represent the means of 18 litter bags from three field sites per regions, 

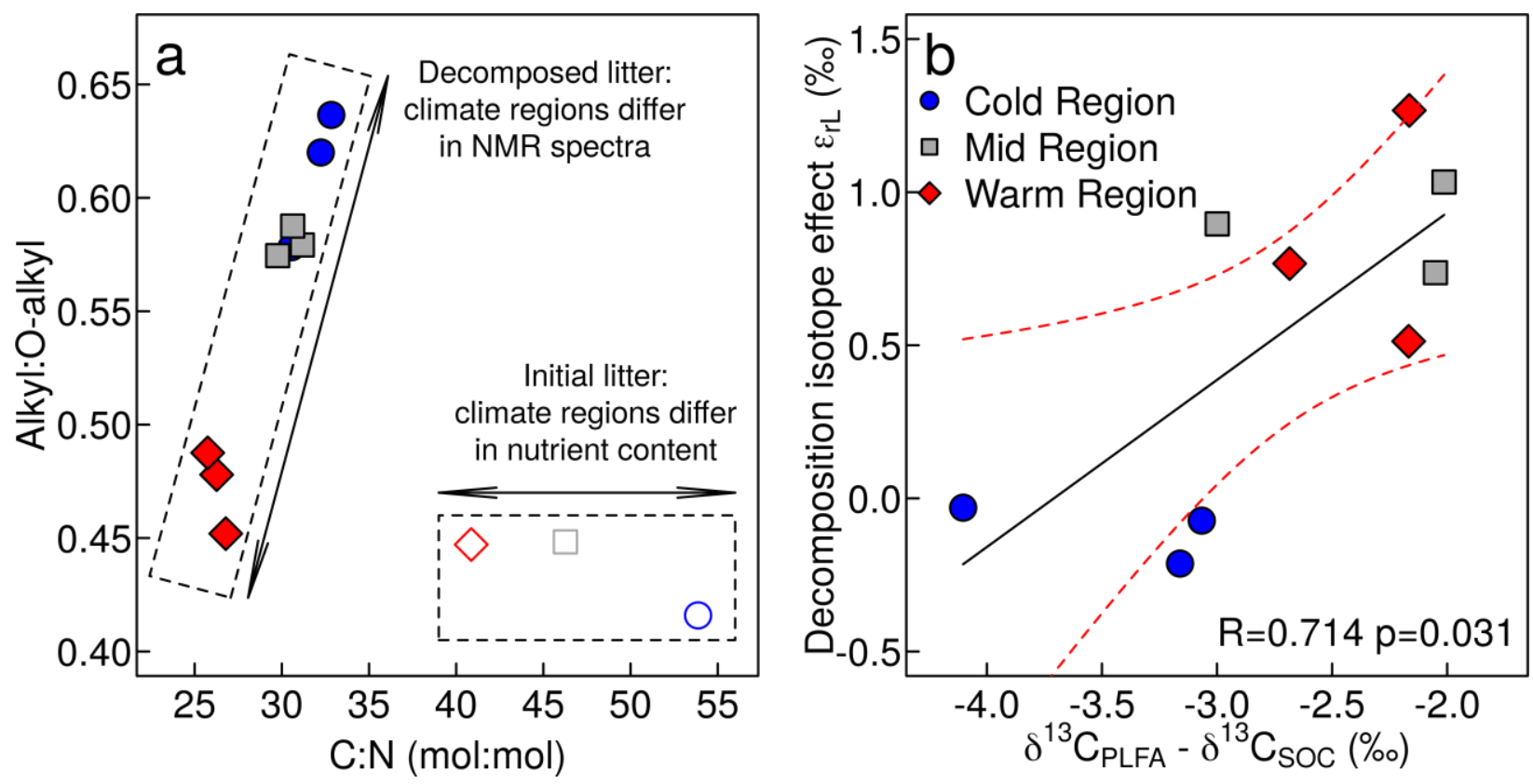

Figure 9. Relationship between C:N ratio and alkyl:O-alkyl ratio in initial (open symbols) and decomposed (closed symbols) litter (a). Furthermore, correlation between the $\delta^{13} \mathrm{C}$ value of microbial biomass measured via PLFA normalized to bulk SOM (and the isotope enrichment effect associated with litter decomposition $\left(\varepsilon_{r L} ; \mathbf{b}\right)$. Symbols and colours indicate transect regions. The solid black line in panel $\mathrm{b}$ indicates the linear regressions between $\delta^{13} C_{P L F A}-\delta^{13} C_{b u l k}$ and $\varepsilon_{r L}$ and the dashed red lines indicating the 95\% confidence interval of this regression. 


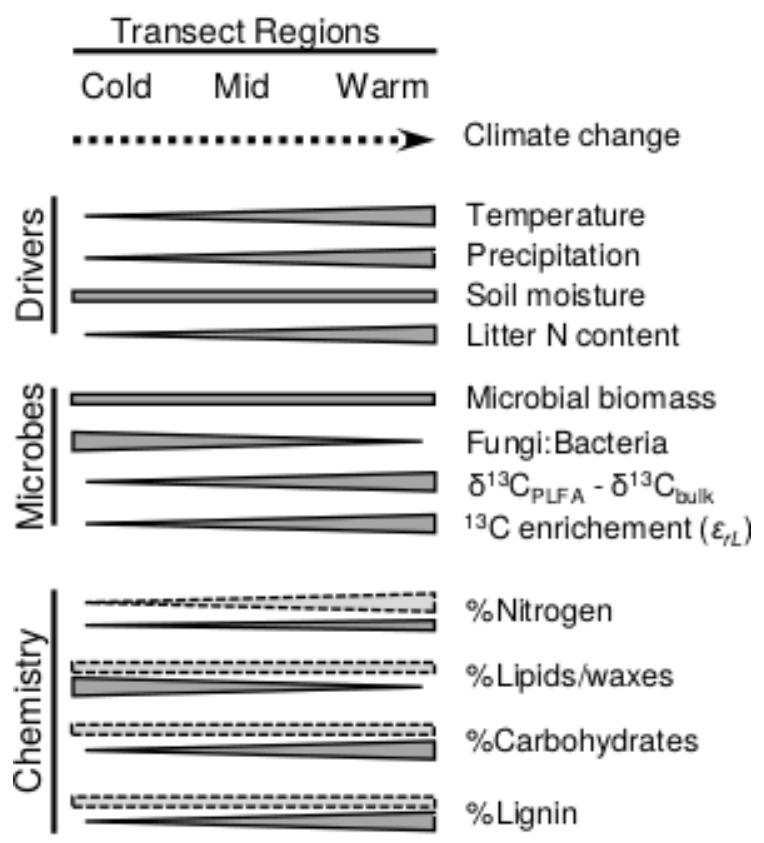

1073 Figure 10. Summary of the effects of climate on environmental controls over litter decomposition, 1074 microbial community structure and isotope effects associated with the microbial decomposition of litter, 1075 and the chemical composition of initial and decomposed litter observed in this study. 


\begin{tabular}{|c|c|c|c|c|c|c|c|c|c|c|c|c|}
\hline Region & Site & Latitude & Longitude & $\begin{array}{c}\text { Elevation } \\
(m)\end{array}$ & $\begin{array}{r}\mathbf{M A T}^{\mathbf{a}} \\
(C)\end{array}$ & $\begin{array}{c}\mathbf{M A P}^{\mathbf{a}} \\
\left(m m \mathrm{a}^{-1}\right)\end{array}$ & $\begin{array}{c}\text { PET }^{\mathbf{a}} \\
\left(m m a^{-1}\right)\end{array}$ & $\begin{array}{c}\text { Litterfall } \\
\left(k g h a^{-1} y r^{-1}\right)\end{array}$ & $\begin{array}{c}\text { Tree basal area } \\
\qquad\left(m^{2} h a^{-1}\right)\end{array}$ & $\begin{array}{c}\text { SOM in LFH } \\
\left(k g S O M-C h a^{-1}\right)\end{array}$ & $\begin{array}{c}\mathbf{C}: \mathbf{N}_{\text {Litterfall }}^{\mathbf{b}} \\
\left(\mathrm{mol} \mathrm{C} \mathrm{mol}^{-1} \mathrm{~N}\right)\end{array}$ & $\begin{array}{c}\mathbf{C}: \mathbf{N}_{\mathbf{L}}^{\mathbf{b}} \\
\left(\mathrm{mol} \mathrm{Cmol} l^{-1} N\right)\end{array}$ \\
\hline \multirow{3}{*}{$\begin{array}{l}\text { Eagle } \\
\text { River } \\
\text { (Cold) }\end{array}$} & Muddy Pond (MP) & $53^{\circ} 33^{\prime} 01 " \mathrm{~N}$ & $56^{\circ} 59^{\prime} 13^{\prime \prime} \mathrm{W}$ & 145 & 0.0 & 1074 & 432 & 1815 & 37.2 & 2430 & 86 & 47 \\
\hline & Sheppar's Ridge (SR) & $53^{\circ} 03^{\prime} 25^{\prime \prime} \mathrm{N}$ & $56^{\circ} 56^{\prime} 02^{\prime \prime} \mathrm{W}$ & 170 & 0.0 & 1074 & 432 & 1992 & 50.1 & 2160 & 87 & 42 \\
\hline & Harry's Pond (HP) & $53^{\circ} 35^{\prime} 12^{\prime \prime} \mathrm{N}$ & $56^{\circ} 53^{\prime} 21^{\prime \prime W}$ & 136 & 0.0 & 1074 & 432 & 2380 & 38.2 & 1950 & 76 & 42 \\
\hline \multirow{3}{*}{$\begin{array}{l}\text { Salmon } \\
\text { River } \\
\text { (Mid) }\end{array}$} & Hare Bay (HB) & $51^{\circ} 15^{\prime} 21^{\prime \prime} \mathrm{N}$ & $56^{\circ} 8^{\prime} 18^{\prime \prime} \mathrm{W}$ & 31 & 2.0 & 1224 & 489 & 4686 & 63.2 & 3130 & 64 & 39 \\
\hline & Tuckamore (TM) & $51^{\circ} 9^{\prime} 51^{\prime \prime} \mathrm{N}$ & $56^{\circ} 0^{\prime} 15^{\prime \prime} \mathrm{W}$ & 16 & 2.0 & 1224 & 489 & 3213 & 39.2 & 3150 & 66 & 37 \\
\hline & Catch-A-Feeder (CF) & $51^{\circ} 5^{\prime} 21^{\prime \prime} \mathrm{N}$ & $56^{\circ} 12^{\prime} 16^{\prime \prime} \mathrm{W}$ & 38 & 2.0 & 1224 & 489 & $19421^{2}$ & 34.0 & 2510 & 65 & 43 \\
\hline \multirow{3}{*}{$\begin{array}{l}\text { Grand } \\
\text { Codroy } \\
\text { (Warm) }\end{array}$} & Slug Hill (SH) & $48^{\circ} 00^{\prime} 39^{\prime \prime} \mathrm{N}$ & $58^{\circ} 54^{\prime} 16^{\prime \prime W}$ & 215 & 5.2 & 1505 & 608 & 4562 & 48.4 & 2880 & 55 & 34 \\
\hline & Maple Ridge (MR) & $48^{\circ} 00^{\prime} 28^{\prime \prime} \mathrm{N}$ & $58^{\circ} 55^{\prime} 14^{\prime \prime W}$ & 165 & 5.2 & 1505 & 608 & 4007 & 44.7 & 3230 & 68 & 34 \\
\hline & O'Reagan's (OR) & $47^{\circ} 53^{\prime} 36^{\prime \prime} \mathrm{N}$ & $59^{\circ} 10^{\prime} 28^{\prime \prime} \mathrm{W}$ & 100 & 5.2 & 1505 & 608 & 5374 & 50.1 & 2910 & 63 & 30 \\
\hline
\end{tabular}

1079

$1080{ }^{\mathrm{a}}$ MAT; mean annual temperature; MAP, mean annual precipitation; PET, annual potential evaporation. Meteorological data represent climate normals 1081 of 1981-2010 from Cartwright, NL; Main Brook, NL; and Doyles, NL weather station and was taken from Environment Canada (2014). Potential

Table 1. Location and characteristics of field sites studied herein. All field sites were located on mature balsam fir (Abies balsamea) stands on well drained podzol soils (specifically, humo-ferric podzols under the Canadian soil classification system). Table updated from Kohl et al., 2015, 2018; Ziegler et al., 2017.

${ }^{b}$ Molar ratio of carbon to nitrogen of foliar litter collected in litter traps $\left(\mathrm{C}: \mathrm{N}_{\mathrm{Litterfall}}\right)$ and of the litter layer $\left(\mathrm{C}: \mathrm{N}_{\mathrm{L}}\right)$. Calculated based upon data in Kohl et al. (2018). 
1085

1086

1087

1088

1089

1090
Table 2. Regional difference in the $\delta^{13} \mathrm{C}$ values of the phospholipid fatty acids (PLFA) relative to soil organic carbon $\left(\Delta^{13} \mathrm{C}_{\mathrm{PLFA}-b u l k}\right)$ and correlation with C:N.

\begin{tabular}{|c|c|c|c|c|c|c|}
\hline \multirow{2}{*}{ PLFA } & \multicolumn{3}{|c|}{$\delta^{13} C_{\text {PLFA }}-\delta^{13} C_{\text {bulk }}$ (median) } & \multirow{2}{*}{$\begin{array}{l}\text { Difference }^{\mathrm{a}} \\
\text { South - North } \\
\end{array}$} & \multicolumn{2}{|c|}{ Correlation with C: $N$} \\
\hline & North & Mid & South & & $\mathbf{R}$ & Slope $^{\mathrm{b}}$ \\
\hline \multicolumn{7}{|l|}{ G+ bacteria } \\
\hline i15:0 & $+2.0 \%$ & $+2.4 \%$ & $+3.0 \%$ & $+1.0 \%$ ** & $-0.42 *$ & -0.041 \\
\hline a15:0 & $-0.8 \%$ & $+0.7 \%$ & $+0.7 \%$ & $+1.5 \% *$ & -0.32 & -0.057 \\
\hline \multicolumn{7}{|l|}{ G+ bacteria } \\
\hline $16: 1 \omega 7$ & $-0.2 \%$ & $+0.9 \%$ & $+1.2 \%$ & $+1.4 \%{ }^{*} * *$ & $-0.59 * *$ & -0.068 \\
\hline су17:0 & $-0.2 \%$ & $+0.2 \%$ & $-0.1 \%$ & $+0.1 \%$ & -0.06 & -0.006 \\
\hline $18: 1 \omega 7$ & $-1.0 \%$ & $-1.1 \%$ & $-0.8 \%$ & $+0.3 \%$ & -0.27 & -0.021 \\
\hline су19:0 & $-0.3 \%$ & $-0.3 \%$ & $-0.3 \%$ & $\pm 0.0 \%$ o & -0.02 & -0.001 \\
\hline \multicolumn{7}{|l|}{ Fungi } \\
\hline $18: 2 \omega 6$ & $-3.1 \%$ & $-3.0 \%$ & $-2.9 \%$ & $+0.2 \%$ & -0.30 & -0.031 \\
\hline $18: 3 \omega 3$ & $-8.5 \%$ & $-7.9 \%$ & $-6.9 \%$ & $+1.8 \% *$ & $-0.57 * *$ & -0.122 \\
\hline \multicolumn{7}{|l|}{ General } \\
\hline 16:0 & $-7.2 \%$ & $-5.0 \%$ & $-5.3 \%$ & $+1.9 \% * *$ & $-0.60 * *$ & -0.102 \\
\hline $18: 1 \omega 9$ & $-1.1 \%$ & $-1.3 \%$ & $-1.5 \%$ & $-0.4 \%$ & +0.13 & 0.016 \\
\hline Weighted mean & $-3.7 \% 0$ & $-2.6 \%$ & $-2.3 \%$ & $+1.3 \% \%^{* * *}$ & $-0.58 * *$ & -0.075 \\
\hline
\end{tabular}

${ }^{a}$ Asterisks indicates significance levels for the Kruskal-Wallace test. *, p $<0.05$; **, $p<0.01, * * *, p<0.001$.

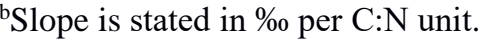


1097

\begin{tabular}{|c|c|c|c|c|c|}
\hline \multicolumn{3}{|c|}{ Assumptions } & \multicolumn{3}{|c|}{ Calculated values } \\
\hline $\mathrm{CUE}_{\mathrm{C}}$ (cold) & $\varepsilon_{\text {biom-bulk }}(\%$ oo $)$ & other & $\Delta \varepsilon_{\text {subs-bulk }}(\%)$ & $\Delta \varepsilon_{\text {biom-subs }}(\%)$ & $\Delta \mathrm{CUE}_{\mathrm{C}}$ \\
\hline \multirow[t]{4}{*}{0.3} & 0 & & $-0.34(-0.39--0.28)$ & $1.46(0.89-2.02)$ & any \\
\hline & any & $\Delta \mathrm{CUE}_{\mathrm{C}}=0$ & $-0.34(-0.39--0.28)$ & $1.46(0.89-2.02)$ & 0 \\
\hline & 2 & $\Delta \varepsilon_{\text {biom-bulk }}=0$ & $1.12(0.50-1.74)$ & 0 & $0.296(0.22-0.35)$ \\
\hline & 5 & $\Delta \varepsilon_{\text {biom-bulk }}=0$ & $1.12(0.50-1.74)$ & 0 & $0.118(0.082-0.15)$ \\
\hline \multirow[t]{4}{*}{0.6} & 0 & & $0.29(-0.01-0.58)$ & $0.83(0.51-1.16)$ & any \\
\hline & any & $\Delta \mathrm{CUE}_{\mathrm{C}}=0$ & $0.29(-0.01-0.58)$ & $0.83(0.51-1.16)$ & 0 \\
\hline & 2 & $\Delta \varepsilon_{\text {biom-bulk }}=0$ & $1.12(0.50-1.74)$ & 0 & $0.158(0.11-0.20)$ \\
\hline & 5 & $\Delta \varepsilon_{\text {biom-bulk }}=0$ & $1.12(0.50-1.74)$ & 0 & $0.058(0.04-0.08)$ \\
\hline
\end{tabular}
Information S4.

Table 3. Mass balance estimates of the difference $(\Delta)$ in the ${ }^{13} \mathrm{C}$-enrichement of substrates relative to bulk litter $\left(\varepsilon_{\text {subs-bulk }}\right)$, the ${ }^{13} \mathrm{C}$-enrichement of biomass relative to substrates $\left(\varepsilon_{\text {biom-subs }}\right)$, and the community-level carbon use efficiency $\left(C U E_{C}\right)$ between warm/mid and cold region required to explain the with measured data. Data from the mid and warm regions was combined due to a lack of difference between these regions. Results are stated as the most likely prediction and the 5-95\% probability range. Positive numbers indicate that the estimate parameter has a higher value in the warm and mid regions compared to the cold region. Details on the method to produce these estimates are provided in Section 2.4 and Supporting 